\title{
Foliage and seeds of malvalean plants from the Eocene of Europe
}

\author{
ZLATKO KVAČEK \& VOLKER WILDE
}

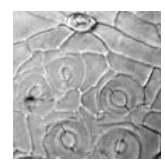

\begin{abstract}
New malvalean plants, based on foliage and seeds, are reported from the Eocene of Germany (Messel), the Czech Republic (Kučlín) and Hungary (Lábatlan). A new morphogenus Byttneriopsis Kvaček \& Wilde morphogen. nov. is provided for Eocene foliage with affinities to the Malvales Juss. fam. Malvaceae Juss. s.l. The representatives from Messel, based on leaf gross morphology and epidermal anatomy, include Byttneriopsis daphnogenes (Ettingshausen) Kvaček \& Wilde comb. nov., Byttneriopsis steuerii (Engelhardt) Kvaček \& Wilde comb. nov. and Byttneriopsis spiegelii (Engelhardt) Kvaček \& Wilde comb. nov. B. daphnogenes also occurs abundantly in Kučlín and Byttneriopsis steuerii in Lábatlan. Winged seeds similar to various Malvales, in particular to Pterospermum Schreb., co-occur at all three localities and are assigned to Saportaspermum Meyer \& Manchester as a new morphospecies Saportaspermum kovacsiae Kvaček \& Wilde sp. nov. Key words: Malvaceae s.l., Eocene, leaves, epidermal anatomy, seeds, Europe.
\end{abstract}

KVAČEK, Z. \& WILDE, V. 2010. Foliage and seeds of malvalean plants from the Eocene of Europe. Bulletin of Geosciences 85(1), 163-182 (9 figures). Czech Geological Survey, Prague. ISSN 1214-1119. Manuscript received October 9, 2009; accepted in revised form November 23, 2009; published online January 21, 2010; issued March 22, 2010.

Zlatko Kvaček, Charles University in Prague, Faculty of Science, Albertov 6, CZ-128 43, Praha 2, Czech Republic; kvacek@natur.cuni.cz・Volker Wilde, Forschungsinstitut Senckenberg, Paläobotanik, Senckenberganlage 25, D-60325 Frankfurt am Main, Germany; Volker.Wilde@senckenberg.de

Systematics of the Malvales Juss. have recently undergone significant modifications. Following exclusion of the Elaeocarpaceae Juss. ex DC., most of the members of this order have been clustered into a single family, Malvaceae Juss. s.l. (Bayer et al. 1999, Bayer \& Kubitzki 2003, Soltis et al. 2005) or split into a larger number of families, namely Sterculiaceae (DC.) Bartl., Pentapetaceae Berch. \& J. Presl, Byttneriaceae R. Br., Durionaceae Cheek, Tiliaceae Juss., Brownlowiaceae Cheek, Sparmanniaceae J.G. Agard., Helicteraceae J.G. Agard., Malvaceae Juss. s.s. and Bombacaceae Kunth. (Cheek 2006, Heywood et al. 2007). As documented by its pollen (for review see Krutzsch 2004), the malvalean group has a considerable geological history. Less straight-forward evidence has been offered by megafossils, in particular foliage. Recently published studies have mostly concentrated on fruits and associated leaves of the Tilioideae Arn. (Manchester 1994, Bůžek \& Kvaček 1994, Kvaček \& Walther 2004 - Tilia L.; Kvaček et al. 2005 - Craigia W.W. Smith \& Evans), while only a few of the remaining megafossils of the malvalean type have been critically re-evaluated (Kvaček 2006, Worobiec et al. work in progress). In the present study we have focused on the leaf and seed compression and impression material from three European sites of Middle and Late Eocene age (Fig. 1) - Messel in Germany (for review see Wilde 1989, 2004, 2005), Lábatlan in Hungary (Kovács
1959, 1961; Erdei \& Rákosy 2009) and Kučlín in the Czech Republic (for review see Kvaček 2002). The material from Messel offers an opportunity to reveal cuticular structures, which may be helpful in the clarification of systematic affinities. At the same time, gross-morphological variation of the respective leaf morphotypes have also been studied. Furthermore, we have tried to evaluate co-occurring seeds potentially corresponding to the studied foliage.

\section{Material and methods}

The oil shale deposited in the maar lake of Messel at Darmstadt in Hesse, Germany, belongs to a world-famous "Lagerstätte", now recognized as a World Heritage Site of fossil biotas (Wilde 2004, 2005; Collinson et al. 2010). The abandoned oil shale mining pit, now under State Protection, has yielded numerous animal and plant fossils. The excellent preservation of leaf compressions, due to the bituminous content, allows detailed studies of anatomy and gross morphology. The rarer three-dimensional fruit and seed fossils, also have preserved anatomical details and flowers which are suitable for analyses of pollen in situ (Schaarschmidt \& Wilde 1986, Wilde \& Schaarschmidt 1993).

The fossil-bearing sediment is fine-grained shale containing high concentrations of microscopic algae (Goth 


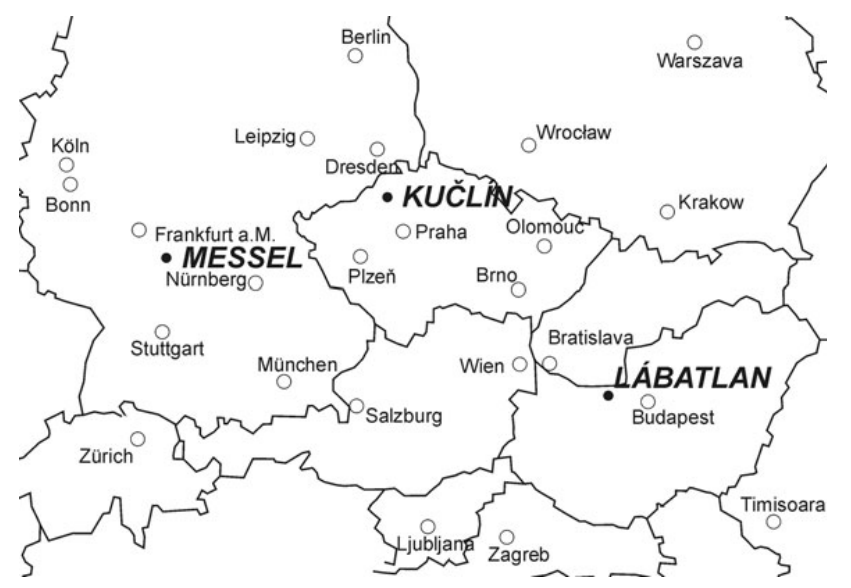

Figure 1. Geographical position of the localities.

1990). The age of the site has been determined, mainly based on palynology, as early Middle Eocene (Lenz et al. 2007). Plant fossils have been known from there since Chelius's (1886) first report. The flora was then described by Engelhardt and posthumously edited by Menzel (Engelhardt 1922). Only after the Second World War a team of scientists from the Senckenberg Museum, Frankfurt/M. began intensive field collections and devised new techniques of preparation with ultrasonic tools, investigation and conservation of plant fossils in glycerol. At the same time, fluorescence microscopy was introduced as a most successful observation technique for these plant fossils (Schaarschmidt 1982). Sturm (1971) and Wilde (1989) began investigations of leaf epidermal anatomy using maceration techniques. Collinson (1988) undertook preliminary surveys of fossil fruits and seeds. The investigations of the fossil flora of Messel have attracted several palaeobotanists to study plant macrofossils from the same location (e.g., Manchester et al. 1994, 2007; Wilde \& Manchester 2003; Wilde \& Frankenhäuser 1999; Wilde et al. 2005; Smith et al. 2009, in press) and these studies are still continuing at the present time.

The collections from Messel are housed partly in the Museum of Darmstadt (MDAR), where most of the original and type specimens published by Engelhardt (1922) are also preserved, and in the Senckenberg Museum, Frankfurt/M. (SM.B). Plant and animal fossil material is also scattered among other institutions, e.g., in the museum at the Messel site and partly in private collections. The type material described by Engelhardt (1922) is kept in MDAR as dry slabs, while most of the specimens at the Senckenberg Museum are submerged in glycerol. Both kinds of the fossil foliage yielded cuticles when macerated with Schulze's solution, the latter were also observed using fluorescence microscopy (Wilde 1989).

The locality of Kučlín in North Bohemia was discovered in the $19^{\text {th }}$ century on the Trupelník Hill (Trippelberg) in the vicinity of Bílina. Radiometric dating indicates it to be Late Eocene (see Kvaček 2002). The fossiliferous rock, a hard beige-colored diatomite, crops out at present in several places at the top of the hill. In addition to the main site, whitish shale containing the same flora crops out beneath the diatomite in the Dead Hill (Mrtvý vrch, Totenberg) at Kučlín. The fossils treated by Ettingshausen (1866-69) were mostly excavated on the slope of the Trupelník Hill from a portion of the diatomite layer shifted by landslide from the original position. The diatomite is deeply weathered and oxidized, so that the fossils are whitish, yellowish impressions without carbonized substance and cuticle remains. Venation is mostly lightly impressed in the rock with many fine details; its reproduction is, however, possible only under very oblique light. Most fossils from Kučlín were concentrated in the so-called Lobkowitz's collection in the castle in Bílina and later sold to Budapest (Hably et al. 2003) including the type and original material published by Ettingshausen (1866-1869). This and later collections made at that time are now housed in the Hungarian Natural History Museum, Budapest (numbers prefixed by BP) and the Austrian Geological Survey (Geologische Bundesanstalt) in Vienna (GBA). Other material excavated at Kučlín during the $19^{\text {th }}$ and $20^{\text {th }}$ centuries is distributed in various collections, namely the National Museum, Prague (specimen numbers prefixed by NM-G), Czech Geological Survey (CGS), Naturhistorische Sammlungen Senckenberg, Dresden Museum für Mineralogie und Geologie Dresden (MMG) and the Headquarters of the Bílina Mines (DB).

Lábatlan is a site of Middle Eocene flora in Hungary (Kovács 1959, Hably 1985). The fossiliferous clay that once cropped out in an abandoned clay pit, represents a clay lens within a substantial freshwater sandy-gravel layer above the Early Eocene limestone (Kovács 1961; Erdei \& Rákosi 2009). The collected impressions and compressions of plant remains are in many cases fragmentary. Although the leaves are covered by carbonized matter, the specimens studied have yielded only poor cuticle fragments on maceration (Kvaček in Knobloch et al. 1996). The whole collection is housed at present in the Hungarian Geological Survey (MAFI) in Budapest.

We have studied living material of the Malvales for comparison, mainly in herbaria of the Museum National d'Histoire Naturelle, Paris (P), British Museum of Natural History, London (BM), Royal Botanic Gardens, Kew (K) as well as in many other places and botanical gardens. The reference collection of epidermal preparations used in this study is housed in the Faculty of Science, Charles University (PRC).

\section{Systematic descriptions}

\section{Order Malvales Juss. ex Bercht. \& J. Presl}

The previous concept of the Malvales, including several families with partly equivocal circumscription (Takhtajan 
1980, 1997; Cronquist 1988; Thorne 1992), has been revised on account of a complex cladistic analysis (Judd \& Manchester 1997) and molecular studies (Alverson et al. 1998, 1999; Worberg et al. 2009). By excluding Elaeocarpaceae Juss. ex DC. from the Malvales, the system of the Malvaceae Juss. sensu lato has become more natural and the reorganization of subordinate families into subfamilies (Bayer \& Kubitzki 2003) more useful. However, one of the latest versions of the malvalean plant systematics (Heywood et al. 2007) again favours the restricted concept of ten families, more restricted than previously. We adhere to Malvaceae s.l., which is in current use (Bayer \& Kubitzki 2003, von Balthazar et al. 2006; Worobiec et al. work in progress) and seems to be more useful in palaeobotanical practice. It is then not surprising that the family Malvaceae sensu lato is recognizable in the fossil state, even as fossil wood (see Manchester et al. 2006), although it is far from uniform with respect to leaf morphology (and also fruits, seeds and pollen, etc.). The typical actinodromous venation is well represented in the majority of the groups, but venation alone is not sufficient to prove malvalean affinities because such a venation type is found abundantly elsewhere among dicots. This was also the reason for much confusion in previous palaeobotanical research which was based on gross-morphology alone. Several palmatelyveined leaf morphotypes which turned to be malvalean were thus assigned to diverse families, such as Moraceae Link. (Ficus L., Cecropia Loefl. - e.g. Heer 1856, 1859; Ettingshausen 1866), Scrophulariaceae Juss. (Paulownia Siebold \& Zucc. - e.g. Laurent 1904-1905), Cornaceae Dum. (Alangium Lam. - Kryshtofovich \& Borsuk 1939), etc. More promising criteria are provided by using a combination of fine venation (Tanai 1989) and epidermal characters, in particular the indumentum (e.g., Knobloch \& Kvaček 1965, Worobiec 2003, Worobiec et al. work in progress). Preliminary comparative studies on epidermal anatomy of various representatives of the Malvaceae s.l. (Worobiec 2003, Worobiec et al. work in progress, Kvaček own observations) suggest that barrel-shaped or clavate glandular trichomes are typical of many malvalean genera and thus are of diagnostic value. On the other hand, other epidermal criteria, such as stomatal type, non-glandular trichomes, the shape of epidermal cells, etc., usually do not circumscribe the natural generic units as understood in extant Malvales. Therefore, the leaf fossils should be assigned to more general categories - morphogenera, even if details of venation and cuticular structures are available.

Considering priority, the earliest published name for such leaves is Dombeyopsis Unger (1850a). The extent of this morphogenus has varied greatly through time (Unger 1850a, Massalongo 1854, Schimper 1874), originally also including dubious and clearly non-malvaceous leaf types such as Cercidiphyllum Siebold \& Zucc. Therefore Kras- silov (1979) strongly rejected Dombeyopsis since its name was not typified by an illustration when published (Unger 1850a). We suggest restricting this morphogenus to include only the type-bearing species Dombeyopsis lobata Unger (type from the Early Miocene Břeštany Clay in the Bílina area in North Bohemia - Kvaček 2004) whose epidermal characters correspond to the Malvaceae s.l. Other occurrences of Dombeyopsis lobata (incl. Dombeyopsis dechenii $\mathrm{C}$. Weber and many other synonyms) are found widespread in the Oligocene, Miocene and even Pliocene of Europe (Worobiec et al. work in progress). The malvalean affinity of these records is confirmed by epidermal anatomy (e.g., Mai \& Walther 1991, Walther \& Kvaček 2007, Kvaček et al. 2008) and/or co-occurrence of fruits of Craigia bronnii (Unger) Kvaček, Bůžek \& Manchester (Kvaček 2004, Kvaček et al. 2005). The other existing malvalean morphogenera for leaves, such as Byttneriophyllum Givulescu ex Knobloch \& Kvaček (1965) and Plafkeria Wolfe (1977) (incl. Actinovena Tanai, 1989) differ in having asymmetric primary venation of the leaf blade. The current concepts for the listed genera are also narrow and restricted to a few species. Byttneriophyllum includes only the species B. tiliifolium (A. Braun) Knobloch \& Kvaček, which regularly co-occurs with fruits of the "giant maple" Banisteriaecarpum Kräusel. Plafkeria, on the other hand, often co-occurs in North America and East Asia with fruits of Craigia oregonensis (Arnold) Kvaček, Bůžek \& Manchester (Kvaček et al. 2005). Relying on the symmetry of the basal venation (but not on the symmetry of the leaf blade) and epidermal characters supporting malvalean affinities, we now define a new morphogenus separated from Dombeyopsis, Byttneriophyllum and Plafkeria in gross morphology, for non-lobate entire-margined leaves occurring in the European Eocene.

\section{Family Malvaceae Juss. nom. cons. s.l.}

\section{Morphogenus Byttneriopsis Kvaček \& Wilde morphogen. nov.}

Description. - Leaves simple, with usually a long, partly geniculate petiole; lamina non-lobate, entire-margined; venation triveined to palmate with all primaries arising directly from the base of the lamina, number of lateral primaries \pm equal on either side of the midrib, tertiary and higher-order veins between primaries percurrent or forked, forming a regular net pattern, areoles reticulate, without free ending veinlets; indumentum including barrel-shaped glandular trichomes or their bases and rarely, thickly cutinized rosette-like complex bases of stellate trichomes.

Type designated here. - Byttneriopsis spiegelii (Engelhardt) Kvaček \& Wilde comb. nov. (Catalpa spiegelii Engelhardt). 
Remarks. - The detailed circumscription of this morphogenus is mainly based on the rich, well preserved material from the Middle Eocene of Messel which enables studies of epidermal characters to be undertaken. Three malvalean leaf morphotypes connected with transitions can be distinguished in this plant taphocoenosis. The critical character supporting malvalean affinities are specific types of trichomes and their bases. Most typical are simple rounded to elliptic bases, on which remains of barrel-shaped polycellular glandular trichomes are occasionally preserved. They correspond to a general form of such trichomes commonly distributed throughout the Malvales. Another kind of pubescence is represented by complex trichome bases as sometimes seen in the material from Messel, which may have carried stellate-multiradiate trichomes. The latter are also characteristic of many members of the malvalean alliance (e.g. Eriolaena DC).

The newly established morphogenus Byttneriopsis may be similar in overall gross morphology to the two other currently used malvalean foliage morphogenera Byttneriophyllum and Plafkeria, which differ especially in the asymmetry of the basal venation. The distinction between Byttneriopsis and Dombeyopsis used by earlier authors in a different sense is less clear. The latter is accepted here in a restricted sense as suggested by Kvaček (2004), viz. to include only the species $D$. lobata typically with trilobate leaves with occasionally undulate to dentate margins and a different abaxial epidermis with a dense indumentum of stellate trichomes. Other leaf forms similar to Byttneriopsis are those of "Ficus" truncata Heer sensu Bůžek (1971), which are also of malvalean affinity and have recently been discussed as possibly related to Reevesia Lindl. (Kvaček 2006). They differ in having a much less regular tertiary and higher-order venation between the primaries and secondaries (Worobiec 2003; Worobiec et al. work in progress).

The delimitation of the morphospecies within Byttneriopsis as described below is complicated by considerable variability in gross morphology and epidermal structures in the Messel specimens, probably due to a differentiation into mesomorphic shade and more xeromorphic sun leaves. The same variation in gross morphology has been found in the population from Kučlín, from which evidence of epidermal anatomy is not available. In addition to gross morphology, we have also considered other diagnostic characters, e.g. stomata (type, form and size), epicuticular sculpture (absence or kind of the striation if present), and the distribution and frequency of trichomes/trichome bases, and distinguished three morphospecies, Byttneriopsis daphnogenes (Ettingshausen) Kvaček \& Wilde comb. nov., Byttneriopsis steuerii (Engelhardt) Kvaček \& Wilde comb. nov., and Byttneriopsis spiegelii (Engelhardt) Kvaček \& Wilde comb. nov. They are probably formal as they are connected at Messel with transitions and may in fact derive from one plant with variable foliage. B. daphnogenes also occurs abundantly at Kučlín, while Byttneriopsis steuerii is common at Lábatlan and Byttneriopsis spiegelii is endemic to Messel.

\section{Byttneriopsis daphnogenes (Ettingshausen) Kvaček \& Wilde comb. nov.}

Figures 2A-J, 3A-E, 7A-H, 8A, B

1866 Ficus daphnogenes Ettingshausen, p. 77 (basionym), pl. 22, figs 1, 2 (lectotype), 8, 9 (Kučlín).

1866 Ficus goeppertii Ettingshausen, p. 73, partim, pl. 19, figs 1,2 (Kučlín).

1866 Ficus reussii Ettingshausen, p. 79, pl. 22, figs 3, 4, 7, 10 (Kučlín, Kostomlaty).

1866 Ficus rueminianum Heer sensu Ettingshausen (non Heer), p. 76, pl. 22, fig. 5 (Kučlín).

?1922 Piper europaeum Engelhardt, p. 33, pl. 5, fig. 4 (Messel).

?1922 Ficus undulata Engelhardt, p. 41, pl. 8, fig. 1 (Messel).

1922 Ficus angustifolia Engelhardt, p. 41, pl. 8, fig. 8 (Messel).

1922 Ficus eocaenica Engelhardt, p. 42, pl. 8, fig. 5 (Messel).

1922 Ficus ovatolanceolata Engelhardt, p. 47, pl. 9, fig. 2 (Messel).

1922 Ficus wetteravica Ettingshausen sensu Engelhardt (non Ettingshausen), p. 46, pl. 10, fig. 4 (Messel).

1922 Ficus thaliae Unger sensu Engelhardt (non Unger), p. 45, pl. 10, fig.7 (Messel).

1922 Ficus michelotii Watelet sensu Engelhardt (non Watelet), p. 45 , pl. 10, fig. 8 (Messel).

1922 Ficus ovatifolia Engelhardt, p. 46, pl. 10, fig. 9 (Messel).

1922 Ficus messelensis Engelhardt, p. 47, pl. 11, figs 3, 4 (Messel).

1922 Ficus titanum Ettinsghausen sensu Engelhardt (non Ettinsghausen), p. 48, pl. 12, fig. 3 (Messel).

Figure 2. Byttneriopsis daphnogenes (Ettingshausen) Kvaček \& Wilde comb. nov., Messel. • A - long petiolate leaf with rounded base and without inflated attachment to the base, i.e. pulvinus refigured from Wilde (1989, pl. 6, fig. 4, as ?Illiciaceae sp.), SM.B Me 929, × 1. • B - detail of leaf base from the previous specimen, $\times 2.5$. $\bullet \mathrm{C}$ - elongate form with cuneate base and prominent pulvinus, SM.B Me $3463, \times 0.8$. $\bullet$ D - detail of leaf base from the previous specimen, $\times 3$. $\bullet$ E - elongate leaf with slightly asymmetrical base and incomplete petiole, SM B Me $1452, \times 1$. $\bullet$ F - elongate leaf with oblique pulvinate petiole, SM.B Me 3297, $\times 1 . \bullet \mathrm{G}-$ twig with broadly ovate long petiolate leaf, SM.B Me $1681, \times 0.7$. $\bullet \mathrm{H}-$ detail of leaf base from the specimen shown in figure $\mathrm{G}, \times 4$. $\bullet \mathrm{I}-$ narrow, ovate long petiolate leaf with less prominent pulvinus, SM.B Me $851, \times 1$. $\bullet \mathrm{J}-$ rounded deformed leaf, SM.B Me $1705, \times 1.5$. - K - Byttneriopsis steuerii (Engelhardt) Kvaček \& Wilde comb. nov., Messel; broad leaf with subcordate base, SM.B Me 748, $\times 1$. (A lower quality of illustrations in Fig. 2 is due to photography through glycerol in which the plant fossils are kept to prevent damage.) 
Zlatko Kvaček \& Volker Wilde - Foliage and seeds of malvalean plants from the Eocene of Europe
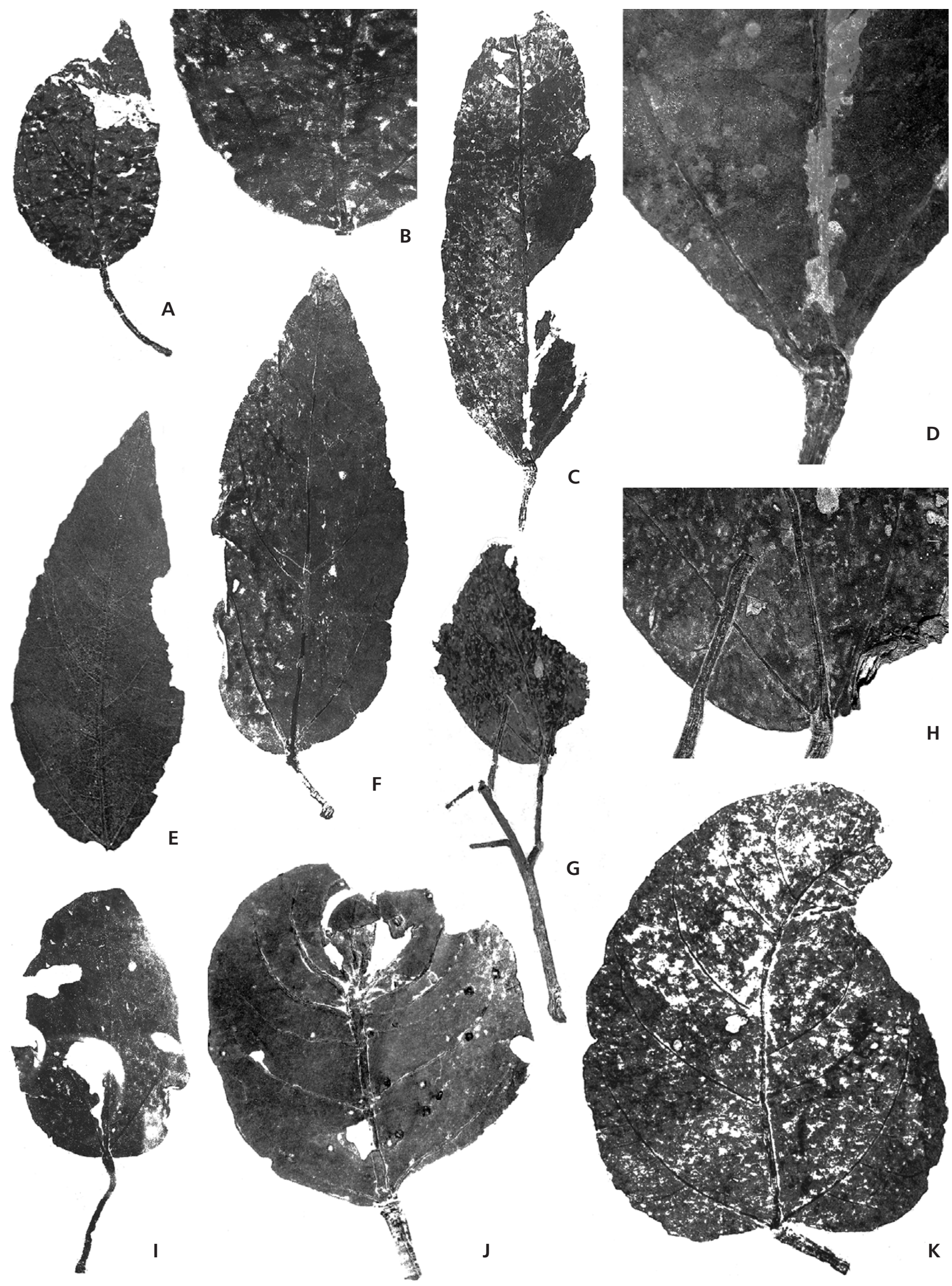

H

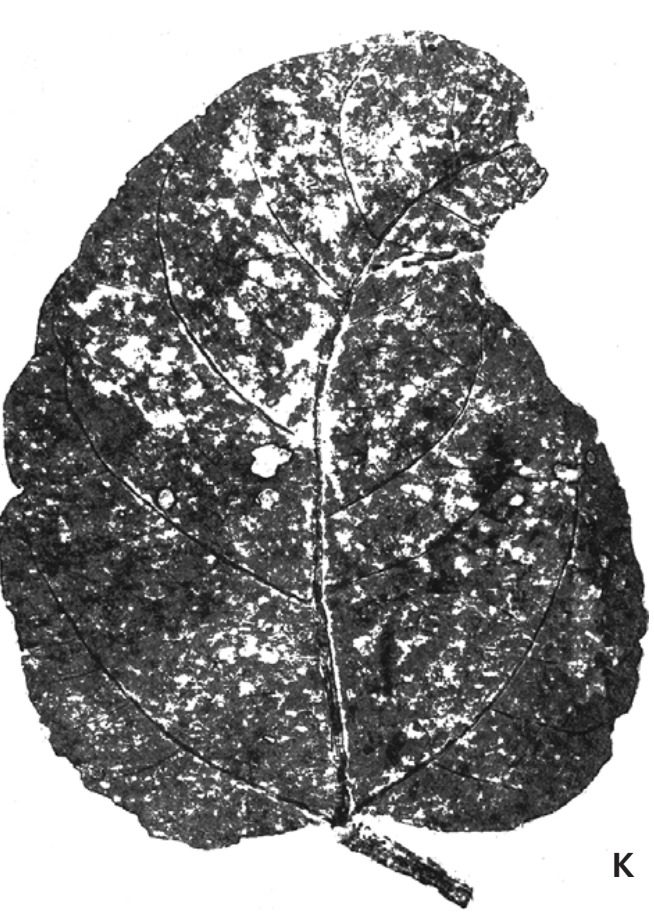


1922 Ficus daphnogenoides Engelhardt, p. 48, pl. 13, fig. 4 (Messel).

1922 Grewia tenuifolia Engelhardt, p. 89, pl. 29, fig. 3, pl. 30, fig. 5 (Messel).

1922 Sterculia grandifolia Engelhardt, p. 88, pl. 29, fig. 5 (Messel).

?1922 Phaseolites eocaenica Engelhardt 1922, p. 111, pl. 37, fig. 9 (Messel).

?1922 Erythrina phaseolites Engelhardt 1922, p. 111, pl.37, fig. 18 (Messel).

1989 Ficus sp. sensu Wilde, p. 37, pro parte, pl. 6, figs 1-3 (Messel).

1989 ?Illiciaceae sp. sensu Wilde, p. 40, pl. 6, figs 4-6 (Messel)

Diagnosis emended. - Leaves simple, entire-margined, non-lobate, often long petiolate, petiole often pulvinate at the lamina base and geniculate, lamina slender elongate to ovate, at the base cuneate to rounded, sometimes slightly asymmetrical, venation brochidodromous, typically triveined; trichomes glandular barrel-shaped or only their simple bases dispersed on the abaxial leaf side together with rare, thickened, rosette-like polycellular trichome bases.

Lectotype designated here. - BP 55.2477.1 (Ettingshausen 1866, pl. 22, fig. 2, illustrated as Ficus daphnogenes and re-illustrated in Hably et al. 2001 and here Figs 3A, E) Kučlín, North Bohemia, Late Eocene.

Additional material. - Messel - SM.B Me 388, 745, 746, 779, 824, 840, 851, 870, 905, 908, 911, 917, 928, 929, 965, $973,975,1355,1388,1400,1419,1424,1428,1430,1432$, $1444,1448,1452,1473,1542,1548,1585,1594,1595$, $1642,1643,1651,1680,1681,1705,1714,1736,1755$, 1863, 1923, 1925, 1928, 3001, 3185, 3297, 3327, 3336, 3345, 3463, 3466, 3563, 3582, 3913; MDAR Me 222 (Sterculia grandifolia Engelhardt, 1922, p. 88, pl. 29, fig. 5 HOLO), ?Me 1906 (Phaseolites eocaenica Engelhardt, 1922, p. 111, pl. 37, fig. 9 HOLO), Me 1998 (Ficus ovatolanceolata Engelhardt, 1922, p. 47, pl. 9, fig. 2 HOLO), Me 2014 (Ficus subdimidiata Engelhardt, 1922, p. 47, pl. 13, fig. 6), Me 3516 (Ficus messelensis Engelhardt, 1922, p. 47, pl. 11, fig. 3), Me 3520 (Ficus eocaenica Engelhardt 1922, p. 42, pl. 8, fig. 5); Kučlín - BP 55.2329.1 (Ficus rueminianum Heer sensu Ettingshausen, 1866, p. 76, pl. 22, fig. 5), BP 55.2358.1 (Ficus reussii Ettingshausen, 1866, p. 79, pl. 22, fig. 10), BP 55.2481.1 (Ficus daphogenes Ettingshausen, 1866, p. 77, pl. 22, fig. 2), DB KUC-53, 160, 199, 200, CGS CB 13 and many other sine numero.

Description. - Leaves alternate, simple, long petiolate, variable in lamina shape and size as well as in epidermal structure, petiole up to $4 \mathrm{~cm}$ long, often pulvinate at the attachment to the lamina and geniculate; lamina entiremargined, hypostomatic, elongate to narrow ovate (length/width ratio usually greater than 1.5 ), 4 to $6 \mathrm{~cm}$ or more in length, 2.5 to $4 \mathrm{~cm}$ wide, symmetrical to moderately asymmetrical, cuneate to rounded at the base, blunt acute at the apex, texture chartaceous to coriaceous, venation brochidodromous, basally triveined, midrib straight or slightly bent, lateral primaries thin, slightly bent, rarely reaching more than half, but usually one third of the lamina length or less, secondaries irregularly alternate, arising at uneven distances of about $1-3 \mathrm{~cm}$, at an angle of $30-45^{\circ}$, bent, tertiaries percurrent or forked, almost perpendicular to the secondaries, areoles mostly quadrangular without veinlets; cuticles medium thick, adaxial cuticle often slightly granular-striated, reflecting polygonal (4-6-sided) cells, 13-28 $\mu \mathrm{m}$ in diameter, anticlinal walls straight or almost straight, abaxial cuticle thinner, smooth except for slight circumstomatal striation, non-modified cells similar to those of the adaxial cuticle, stomata in intercostal areas only, dense, circular to widely oval, partly with polar I-pieces, ledges double thickened, surrounding widely open aperture, stomatal type not always recognizable, incompletely to regularly cyclocytic, rarely anomocytic, trichome bases of two types: simple rounded, 10-15 $\mu \mathrm{m}$ in diameter, surrounded by radial subsidiary cells, partly with remains of obconical basal cell, exceptionally with the barrel-shaped distal part up to $25 \mu \mathrm{m}$ wide composed of two layers of small segment cells, longitudinally orientated, scattered to densely dispersed all over the abaxial epidermis; complex rosette-like thickly cutinized bases of stellate trichomes up to $40 \mu \mathrm{m}$ in diameter, solitary on veins.

\section{Byttneriopsis steuerii (Engelhardt) Kvaček \& Wilde comb. nov.}

Figures 2K, 3F, 4A-D, 5E, 6C-E, 8C, D

1922 Pterospermum steuerii Engelhardt, p. 89 (basionym), pl. 27, fig. 3 (Messel).

Figure 3. Byttneriopsis daphnogenes (Ettingshausen) Kvaček \& Wilde comb. nov., Kučlín. • A - lectotype re-illustrated from Ettingshausen (1866, pl. 22, fig. 2, as Ficus daphogenes), standard form with rounded base and incomplete pulvinate petiole, BP 55.2477.1, $\times 1.5 . \bullet$ B - elongate form with less distinctly pulvinate petiole. ČGS ČB $13, \times 1 \cdot \bullet \mathrm{C}$ - elongate form with stout petiole, DB KUC $52, \times 1 . \bullet \mathrm{D}-$ extremely long petiolate elongate leaf, DB KUC 53, $\times 1 . \bullet$ E - detail of leaf base from the lectotype shown in Fig. 3A, $\times 3 . \bullet F-$ Byttneriopsis steuerii (Engelhardt) Kvaček \& Wilde comb. nov., Kučlín; fragment of a broad subcordate leaf, $\times 1$. 

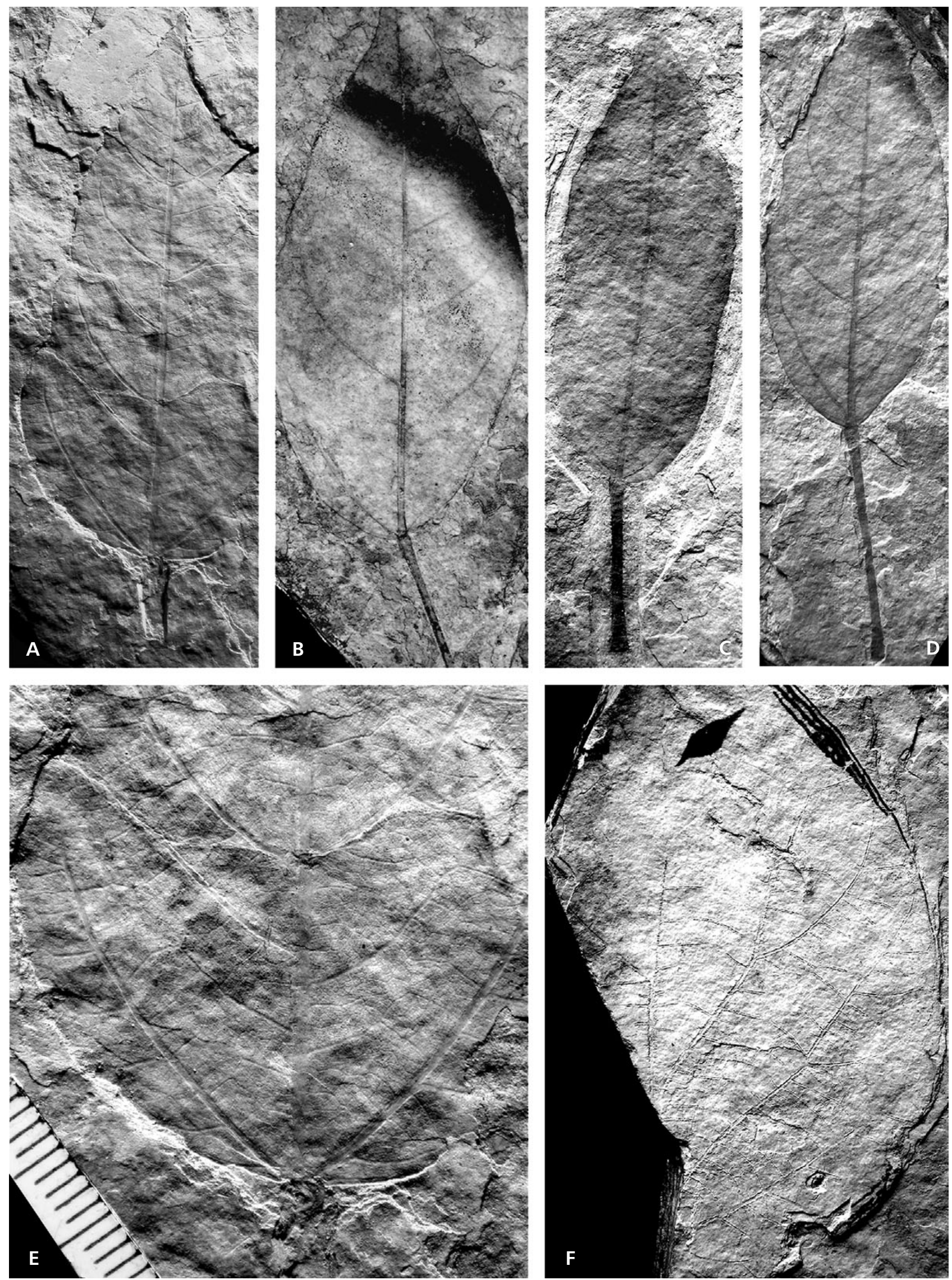
1922 Macropiper rotundifolium Engelhardt, p. 33, pl. 6, fig. 2 (Messel).

1922 Ficus populifolia Engelhardt, p. 44, pl. 10, fig. 5 (Messel).

1922 Ficus planicostata Lesquereux sensu Engelhardt (non Lesquereux), p. 45, pl. 10, fig. 6 (Messel).

1922 Ficus tiliifolia A. Braun sensu Engelhardt (non A. Braun), p. 49, pro parte, pl. 11, fig. 5 (Messel).

1922 Ficus rotundifolia Engelhardt, p. 49, pl. 11, fig. 6 (Messel).

?1922 Ficus subdividiata Engelhardt, p. 47, pl. 13, fig. 6 (Messel).

1922 Populus mutabilis Heer sensu Engelhardt (non Heer), p. 61, pl. 18, fig. 6 (Messel).

1922 Grewia microcoides Engelhardt, p. 89, pl. 30, fig. 9 (Messel).

1922 Grewiopsis sp. sensu Engelhardt, p. 90, pl. 30, fig. 10 (Messel).

?1959 Grewiopsis inaequalis É. Kovács, p. 136, fig. 3 (Lábatlan).

1959 Byttneria apiculata É. Kovács, p. 137, figs 4-6 (“Buettneria") (Lábatlan).

1961 Byttneria apiculata É. Kovács sensu É. Kovács, p. 474, pl. 1, figs 4, 5 (Lábatlan).

1989 Byttneriophyllum tiliifolium (Al. Braun) Knobloch \& Kvaček sensu Wilde [non (Al. Braun) Knobloch \& Kvaček], p. 71, pl. 20, figs 4a-c (Messel).

Diagnosis emended. - Leaves similar to Byttneriopsis daphnogenes both in detailed venation and epidermal anatomy, but lamina broadly ovate to suborbicular, at the base truncate to cordate, venation triveined tending towards actinodromy, with 2-4 additional lateral primaries.

Holotype designated here. - MDAR Me 1637 (Pterospermum steuerii Engelhardt, 1922, p. 89, pl. 27, fig. 3 and re-illustrated here in Fig. 4C, D and cuticle in Fig. 8D) Middle Eocene, Messel.

Additional material. - Messel - SM.B Me 749, 908, 1428 (Byttneriophyllum tiliifolium (Al. Braun) Knobloch \& Kvaček sensu Wilde, 1989, p. 71, pl. 20, fig. 4a-c), 1707, 1893, MDAR Me 3524 (Grewia microcoides Engelhardt, 1922, p. 89, pl. 30, fig. 9); Kučlín - DB KUC 51, 218; Lábatlan - MAFI 3448 (L 15), 3476 (L 23), 3486 (L 28) (Byttheria apiculata É. Kovács, 1959, p. 137, fig. 4), 3566 (L 150) (Byttneria apiculata É. Kovács, 1959, p. 137, fig. 5 counterimpression), 3554 (L 154), 3563, 3588, 3593 (Byttheria apiculata É. Kovács, 1959, p. 137, fig. 6), 3695, ?3452 (L 9) and counterimpression 3566 (L 150) (Grewiopsis inaequalis É. Kovács, p. 136, fig. 3).

Description. - Leaves simple, long petiolate, petiole often incomplete, partly pulvinate, lamina broadly ovate to subor- bicular, up to more than $12 \mathrm{~cm}$ long and $10 \mathrm{~cm}$ wide, at base truncate, shallowly to deeply cordate, apex bluntly acute to acuminate, venation actinodromous-brochidodromous, typically palmately 5 to 7 -veined, \pm symmetrical, texture chartaceous; adaxial cuticle smooth, reflecting polygonal cells ca 20-25 $\mu \mathrm{m}$ in diameter, with straight to slightly curved anticlines, abaxial cuticle thin, partly faintly striate, composed of non-modified cells $c a 15-25 \mu \mathrm{m}$ in diameter with slightly curved anticlines, stomata sub-circular, $15 \mu \mathrm{m}$ long, with narrow elliptic apertures and less thickened stomatal ledges, stomatal type incompletely cyclocytic to anomocytic, bases of trichomes of the same type as in Byttneriopsis daphnogenes, but much rarer or solitary.

Remarks. - Byttneriopsis daphnogenes is much more frequent than the more mesomorphic Byttneriopsis steuerii in both Messel and Kučlín, while the latter occurs more frequent only at Lábatlan (as Byttneria apiculata). The exact separation of the two morphospecies is somewhat vague due to transitions. Although epidermal characters are only known for the material from Messel, we do not hesitate to merge both the Messel, Lábatlan and Kučlín populations into two variable entities on account of similarities in gross morphology. The lectotype of Byttneriopsis daphnogenes from Kučlín and other specimens from this Late Eocene locality (Fig. 3A-I) are morphologically indistinguishable from an overwhelming part of the Messel material, comprising mostly triveined forms rounded and symmetrical at the base and long petiolate, often pulvinate at the attachment to the blade; these diagnostic characters may serve as a basis for recognition of these leaf morphotypes elsewhere, e.g. in the Eocene site Kostomlaty not far from Kučlín (Ettingshausen 1866, as Ficus reussii Ettingshausen). Byttneriopsis daphnogenes and Byttneriopsis steuerii are similar in the overall variation of lamina shape, compared to the even more variable Miocene Ficus truncata Heer (as circumscribed by Bůžek 1971) with cuneate to deeply cordate leaves (see Kvaček 2006). The latter is distinguished by irregular, coarse and wider disposition of tertiary venation and by its epidermal characters (Worobiec 2003; Worobiec et al. work in progress).

Byttneriopsis steuerii is morphologically similar to Pterospermum chattanum Engelhardt (1922, p. 89, pl. 30, fig. 6), which belongs to the Lauraceae and differs in subbasal secondaries and leaf anatomy (internal oil cells, different simple trichome bases).

\section{Byttneriopsis spiegelii (Engelhardt) Kvaček \& Wilde comb. nov.}

Figures $6 \mathrm{~A}-\mathrm{C}, 8 \mathrm{E}, \mathrm{F}$

1922 Catalpa spiegelii Engelhardt, p. 70 (basionym), pl. 22, fig. 1 (Messel). 

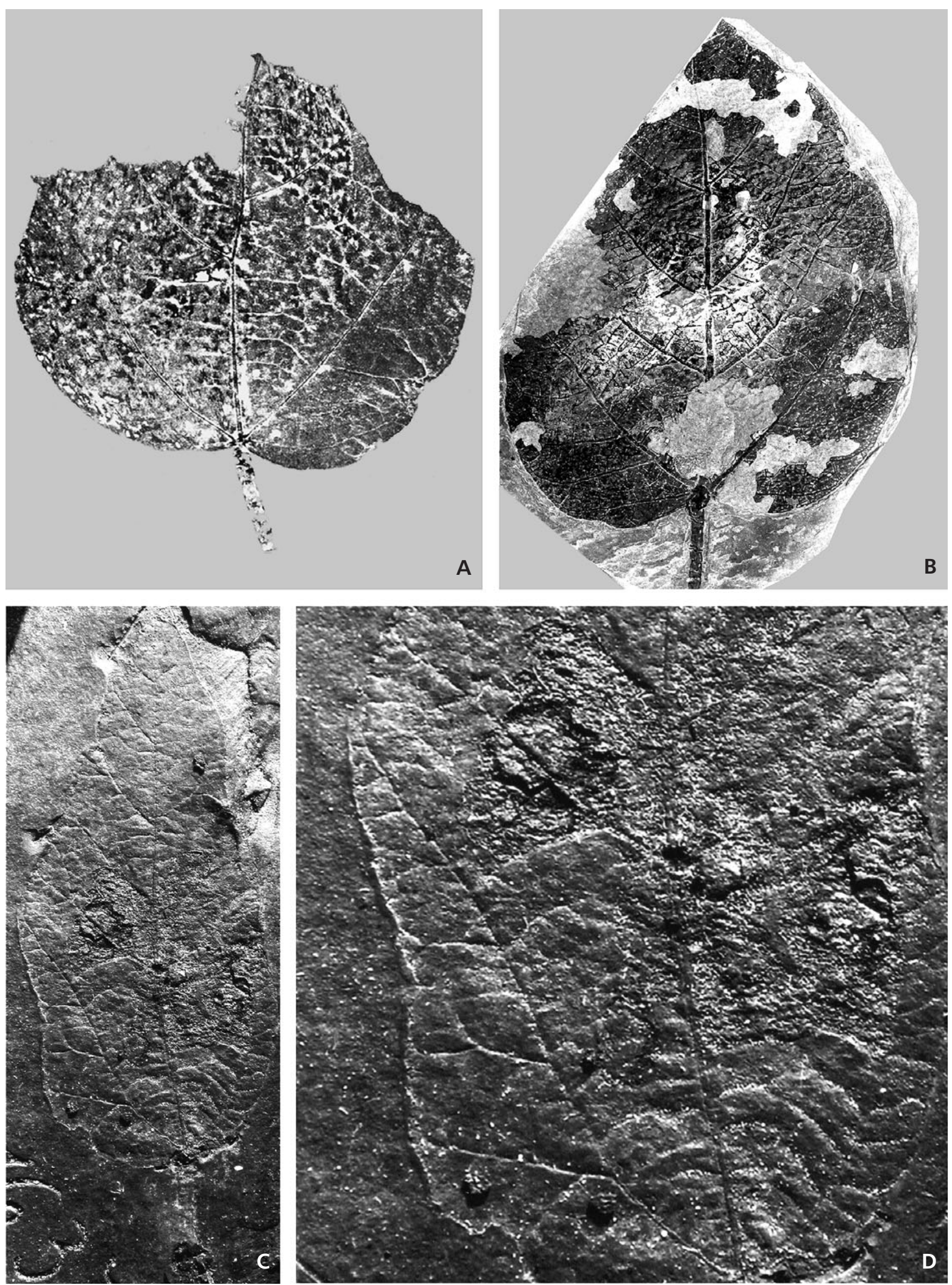

Figure 4. Byttneriopsis steuerii (Engelhardt) Kvaček \& Wilde comb. nov., Messel. • A - subcordate leaf without pulvinus, SM.B Me $908, \times 1$. - B - cordate leaf with distinctly pulvinate petiole refigured from Wilde (1989, pl. 20, figs 4a-c, as Byttneriophyllum tiliaefolium), SM.B Me $1428, \times 0.7$. - C - short ovate, petiolate leaf with truncate asymmetrical base and without pulvinus, holotype refigured from Engelhardt (1922, p. 89, pl. 27, fig. 2, as Pterospermum steuerii), MDAR Me $1637, \times 1.5 . \cdot \mathrm{D}-$ detail of the same specimen, $\times 3$. 
1922 Ficus tiliaefolia (Al. Braun) Heer sensu Engelhardt (non (Al. Braun) Heer), p. 49, pro parte, pl. 12, fig. 5 (Messel).

1922 Cercis grandifolia Engelhardt, p. 114, pl. 38, fig. 1 (Messel).

?1922 Cecropia europaea Ettingshausen sensu Engelhardt (non Ettingshausen), p. 60, pl. 18, fig. 3 (Messel).

Holotype designated here. - Specimen No. MDAR Me 3436 (Me027) (Museum Darmstadt) (illustrated in Engelhardt (1922) as Catalpa spiegelii Engelhardt, p. 70, pl. 22, fig. 1 and re-illustrated here - Fig. 6A-C and cuticles in Fig. 8E, F) - Middle Eocene, Messel.

Additional material studied. - MDAR Me 79 (Ficus tiliaefolia (Al. Braun) Heer sensu Engelhardt 1922, p. 49, pl. 12, fig. 5).

Description- Leaves long petiolate, petiole not pulvinate, lamina non-lobate, entire-margined, broadly ovate to orbicular, up to $20 \mathrm{~cm}$ wide and over $22 \mathrm{~cm}$ long, deeply cordate at base, apex probably convex, venation actinodromous-brochidodromous, typically palmately 5 to 7-veined, \pm symmetrical. Adaxial cuticle smooth, reflecting polygonal cells $c a 20-25 \mu \mathrm{m}$ in diameter, with straight to slightly curved anticlines, abaxial cuticle faintly striate, composed of non-modified cells $c a 15-25 \mu \mathrm{m}$ in diameter with slightly curved anticlines. Stomata subcircular, $15 \mu \mathrm{m}$ long, with narrow elliptic aperture and unthickened stomatal ledges. Stomatal type anomocytic to incompletely cyclocytic. Solitary rounded trichome bases, rarely distal parts of barrel-shaped glandular trichomes preserved, consisting of a basal funnel-shaped cell and thin-walled multicellular head divided into segments parallel to the trichome length.

Remarks. - Byttneriopsis spiegelii co-occurs in Messel with $B$. daphnogenes and B. steuerii. We separate these rare, extremely large leaves on account of differences in both gross morphology (deeply cordate forms) and epidermal anatomy (very thin striated abaxial cuticles with indistinctly cutinized stomata). In our opinion, it is very probable that they might represent mere aberrant leaf forms of B. steuerii. Byttneriopsis spiegelii is similar in gross morphology to the non-lobate entire-margined forms of Dombeyopsis lobata (e.g., Kvaček 2004, fig. 4.2) in the deeply cordate base of the lamina, a stout stalk, and almost symmetrically disposed primaries, but differs from it in the epidermal anatomy. In contrast to Byttneriopsis spiegelii, Dombeyopsis lobata, representing foliage of Craigia bronnii (Oligocene to Pliocene of Europe, Kvaček et al. 2005), has the underside covered by stellate trichomes (Knobloch \& Kvaček 1976, Kvaček 2004) while the leaves of Byttneriopsis spiegelii are glabrescent. Another common malvalean foliage type known as Byttneriophyllum tiliifolium (Miocene to Pliocene of Europe and East Asia), also has a dense cover of stellate trichomes on the abaxial epidermis (Knobloch \& Kvaček 1965, Worobiec 2003), but differs decidedly in the typically oblique leaf base and unequally disposed lateral primaries emerging from the midrib.

\section{The associated seeds}

\section{Morphogenus Saportaspermum Meyer \& Manchester}

The winged seeds, which were included in this morphogenus (type S. occidentale Meyer \& Manchester 1997, p. 161, pl. 74, figs 14-20, Oligocene of the John Day Formation, Oregon), are typical of those wings either without or with very feebly visible veins. Contrary to similar seeds of the Pinaceae, the seed body is attached to the wing dorsally, not laterally. In addition to the type described by Meyer \& Manchester (1997) from the Oligocene of North America, similar small seeds have been recorded in the Paleogene and Miocene of Europe (see, e.g. Bůžek et al. 1976, pl. 12, figs 6-9, as "Embothrium" cf. salicinum Heer from the Oligocene of Markvartice, N Bohemia; Kovar-Eder et al. 2004, pl. 15, figs 6-8, as Saportaspermum sp. from the Miocene of Parschlug, Styria). Specimens corresponding with the type of the genus (Hably et al. 2000) were described under various species names and await taxonomic revision. In one such case, seeds were found in the Lower Miocene of Bílina, North Bohemia in association with the fruits of Reevesia (Kvaček 2006). In other cases, affinities are uncertain. Bigger seeds, similar to the new morphospecies described below, occur in the Early Oligocene site of Seifhennersdorf (as Saportaspermum dieteri Walther \& Kvaček, 2007) and differ only in subtle details (see below). The species differences within Saportaspermum are certainly not very pronounced.

\section{Saportaspermum kovacsiae Kvaček \& Wilde sp. nov.} Figures 9A-H

1959 Cedrelospermum sp. type I sensu É. Kovács, p. 140, fig. 7 (Lábatlan, MÁFI).

1959 Cedrelospermum sp. type II sensu É. Kovács, p. 140, fig. 8 (Lábatlan, MÁFI).

1961 Cedrelospermum sp. type I sensu É. Kovács, p. 474, pl. 1, fig. 6 (Lábatlan, MÁFI).

Diagnosis. - Seeds winged, with an elliptical to sub-orbicular seed body, strengthened at the base and somewhat pointed at the opposite end, with a single narrow elongate membranaceous wing; surface of the seed body with more or less visible striation from alignment of surface cells. Seed body orientated obliquely to the long axis of the wing $\left(30-40^{\circ}\right)$; one of the lateral margins straight, the other 

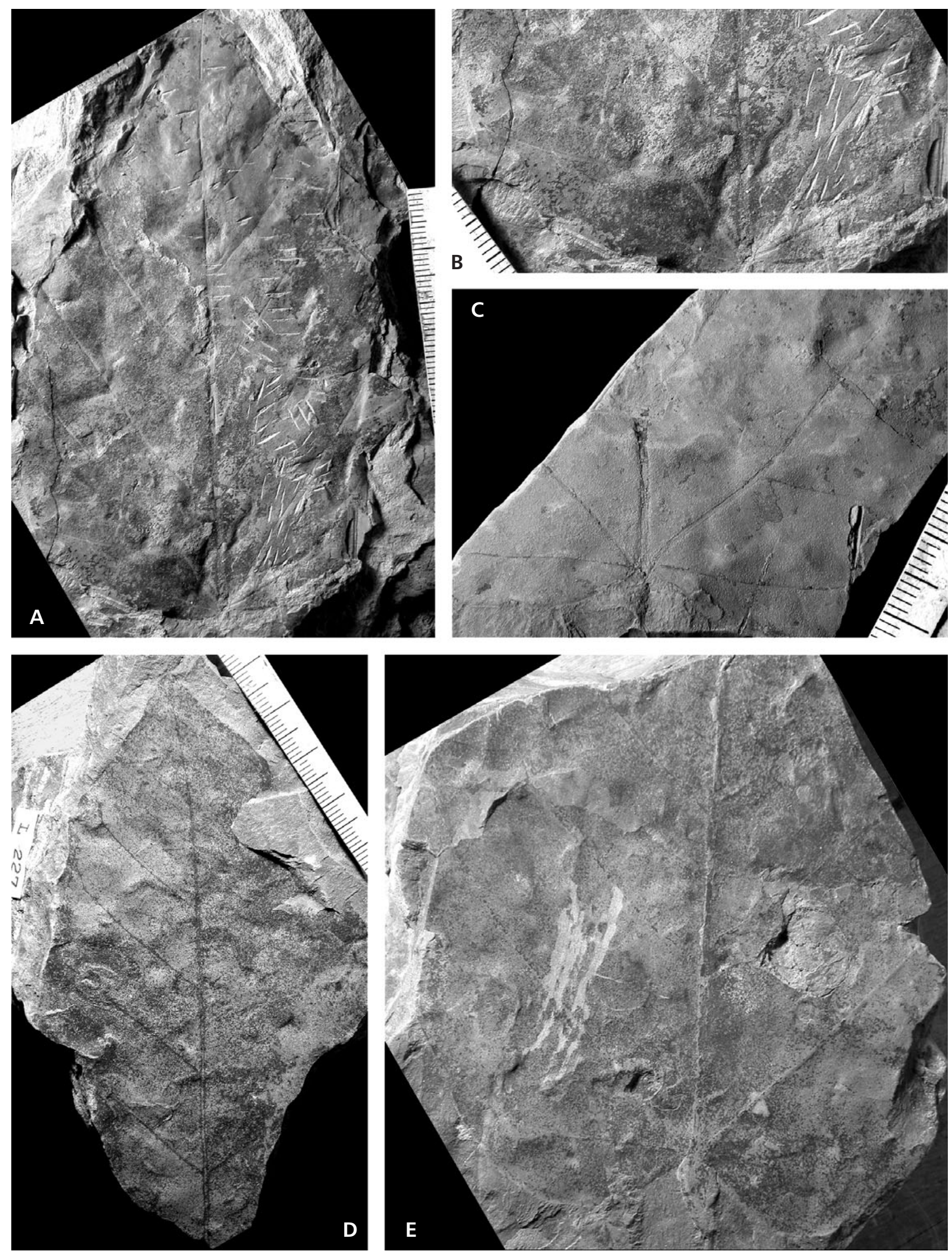

Figure 5. Byttneriopsis steuerii (Engelhardt) Kvaček \& Wilde comb. nov., Lábatlan. • A - holotype of Byttneria apiculata É. Kovács (1959, fig. 4), MAFI Bk 3485 (L 28), $\times 1$ 1 • B - detail of leaf base from the previous specimen, $\times 1.5$. $\bullet$ C - incomplete subcordate leaf base, MAFI Bk 3476 (L 23 ) $\times 1.5$. - D - incomplete leaf showing leaf apex, MAFI Bk 3588 (L 227), × 1. E - incomplete leaf with cordate base re-illustrated from Kovács (1959, fig. 6), MAFI Bk 3593 (L 14), × 1.3. 


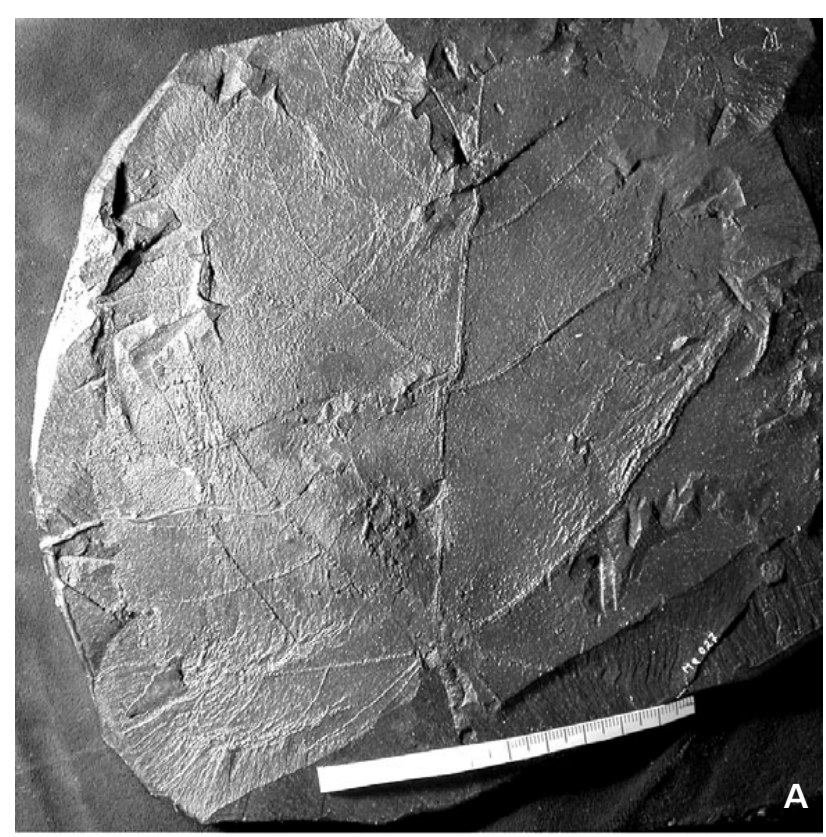

Figure 6. Byttneriopsis spiegelii (Engelhardt) Kvaček \& Wilde comb. nov., Messel. - A - holotype (= type of Byttneriopsis Kvaček \& Wilde morphogen. nov.), large leaf without apex, MDAR Me 3436, refigured from Engelhardt (1922, p. 70, pl. 22, fig. 1 as Catalpa spiegelii Engelhardt). $\times 0.8 . \bullet \mathrm{B}, \mathrm{C}-$ details of marginal area and base with attachment of petiole from the previous specimen, $\times 2$.

slightly convex, distal end of wing rounded; venation-like structure on the straight margin.

Holotype designated here. - SM.B Me 5587, illustrated in Fig. 9A - Middle Eocene, Messel.

Etymology. - The epithet is established in recognition of Mrs. Éva Kovács, a Hungarian palaeobotanist and the first discoverer of such fossils in the Eocene of Hungary.

Description. - Several morphotypes connected with transitions can be recognized and assigned here to the same species, expressing, in our opinion, merely different stages of maturation:

Cedrelospermum sp. type I sensu Kovács (1959, p. 140, fig. 7 - Lábatlan, MAFI BK 3460/5/a) (Fig. 8C, F) and most of the material from Messel and Kučlín represent fully mature seeds with a robust seed body, sometimes truncate or with a more acute base, $c a 9 \mathrm{~mm}$ long and 4-6 mm high. The wing is almost parallel-sided, slightly narrowed towards the end, 22 to $28 \mathrm{~mm}$ long. The dorsal side of the wing is straight, slightly thickened and indis-
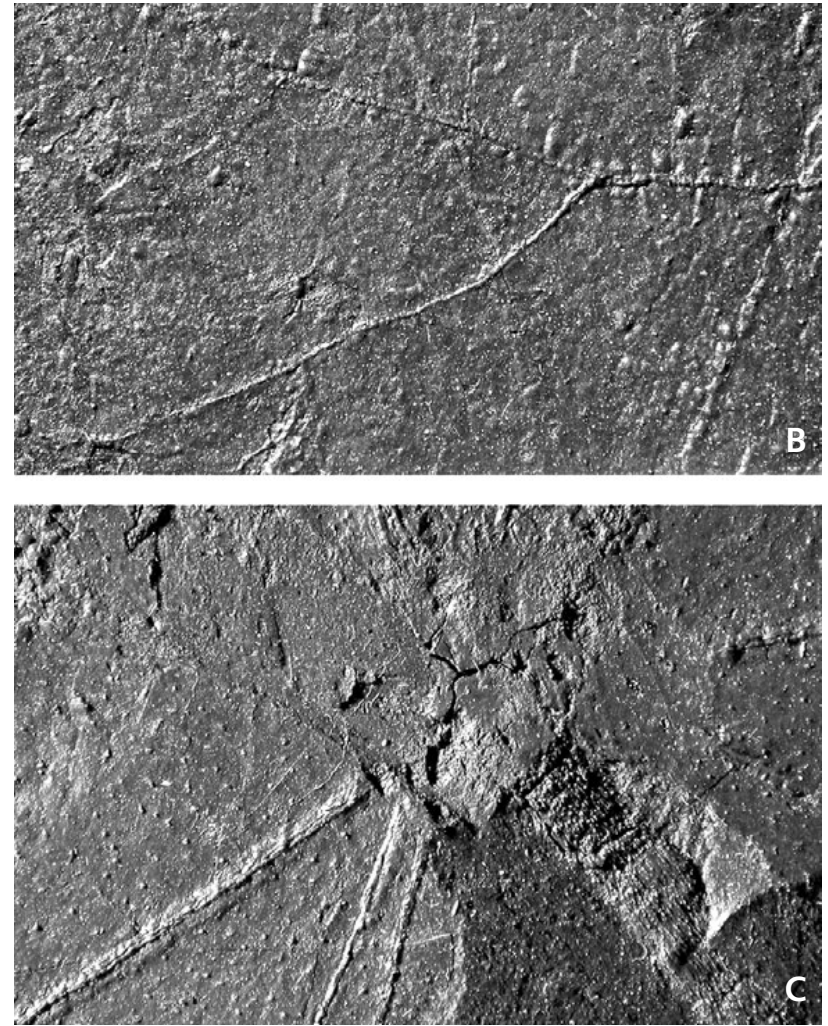

tinctly deflected behind the seed body; the ventral side is also straight. Under high magnification, the wing appears partly faintly striated due to strands forming the surface tissue. The specimens from Lábatlan designated as Cedrelospermum sp. type II sensu Kovács (1959, p. 140, fig. 8, MAFI BK 3526/L 107 and other not figured material BK $3487 / \mathrm{L} 26,24)$ are smaller than the previous morphotype I with the wing $16 \mathrm{~mm}$ long, the dorsal side straight or slightly bent and the ventral side straight (Fig. 9D, E). A specimen from Messel (SM. B Me 4115) with the seed body narrowed and at the base partly beak-like (Fig. 8B), finely pitted on the surface, $9 \mathrm{~mm}$ long and $4 \mathrm{~mm}$ tall, attached obliquely to the $22 \mathrm{~mm}$ long wing, may belong to the same morphotype because of variation in winged seeds being common in the Malvaceae due to variable position in the fruit capsule (e.g. in Pterospermum - Fig. 9K, L).

Additional material studied. - Messel - SM.B ME 2181, 4115, 7224, 8380 (part and counterpart) 1645517019 , 16836, 17836, 17020, 19885, 19950, 20181, 21620, 21622, 21809; Lábatlan - MÁFI BK 3460, BK 3487, BK 3526; Kučlín, Dead Hill (Mrtvý vrch, Totenberg) - DB KsMr01.

Figure 7. Byttneriopsis steuerii (Engelhardt) Kvaček \& Wilde comb. nov., cuticular structures of specimen SM.B Me 908 shown in Fig. 4A from Messel. $\bullet$ A - abaxial cuticle showing incompletely cyclocytic stomata. $\bullet$ B - abaxial cuticle showing incompletely cyclocytic stomata and base of a glandular trichome. $\bullet \mathrm{C}$ - adaxial cuticle with straight to curved anticlines, D, E - detail of stomata. $\bullet \mathrm{F}$ - small compound trichome base, $\mathrm{G}-$ massive compound trichome base of stellate trichome. $\bullet \mathrm{H}-$ glandular barrel-shaped trichome on abaxial cuticle. All figures $\times 600$ except $\mathrm{D}, \mathrm{E}$, and $\mathrm{H} \times 1500$. 

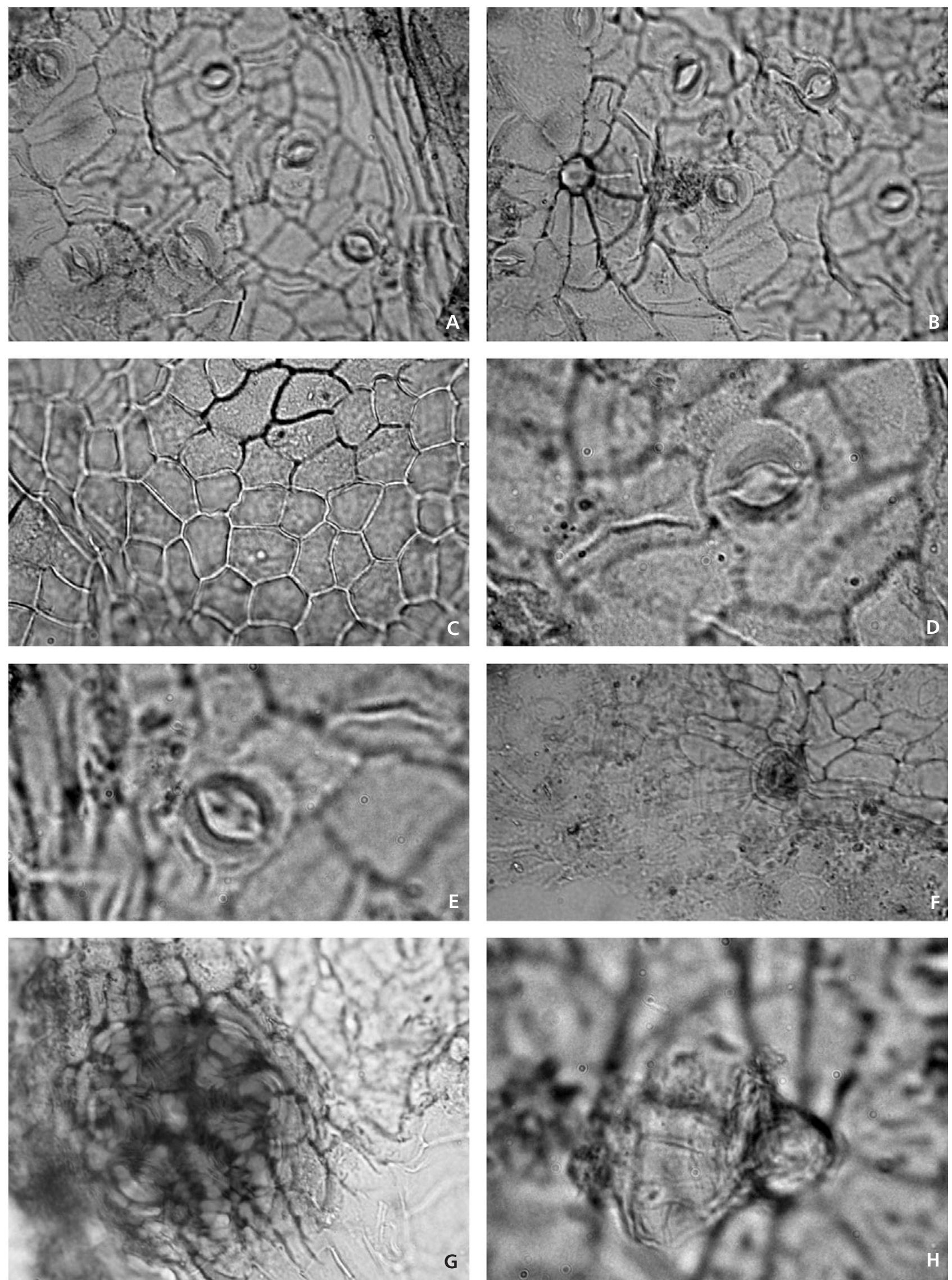
Remarks. - This type of seeds accompanies the foliage of Byttneriopsis daphnogenes as well as B. steuerii at all the three localities studied. Such winged seeds are known in several genera of the Malvaceae s.l., e.g., Pterospermum, Eriolaena, Reevesia, Nesogordonia Baill, etc. An assignment of such seeds to Cedrelospermum Saporta as suggested by Kovács (1959) is now inappropriate since Manchester (1987) re-defined this genus to include only fruits of the samara type belonging to an extinct member of the Ulmaceae (type Cedrelospermum aquense (Saporta) Saporta, Late Oligocene, Aix-en-Provence). The previously widely adopted morphogenus Embothrites Unger (type Embothrites borealis Unger, 1850a, p. 428, 1850b, p. 171, partim, pl. 21, figs 11, 12 (non fig. 10 - leaf), Upper Eocene in Socka - see Manchester 1987, 1989) is now restricted to those winged seeds with a sub-circular seed body attached directly by a neck to the elliptical wing, which is about twice as long as the seed body and shows fine dichotomous venation (Manchester 1987, type in pl. 3, figs 3, 4).

The seeds of Gordonia Ellis., both fossil and extant (Grote \& Dilcher 1992), appear similar to our fossils, but differ in the oblique orientation of the seed body towards the apical wing and the position of the hilum and the dorsal part. A similar type of fossil winged seeds was described within the morphogenus Saportaspermum as S. occidentale Meyer \& Manchester (1997), which is characterized by an ovate to elliptical seed body orientated obliquely (at an angle of $40^{\circ}$ ) to the lateral elongate wing, without apparent veins. The position of the hilum has not been indicated. The seed body continues into the dorsal part of the wing by a distinct tapered raphe, without any indentation, and there is also no distal notch, contrary to Cedrelospermum fruits. The seeds from Messel may be assigned to Saportaspermum (Collinson et al., work in progress) and we agree with this generic assignment. The Saportaspermum type of seed was widespread from the Oligocene to the Miocene of Europe (e.g., Hably et al. 2000) and has usually been assigned to Embothrium salicinum (Ettingshausen) Heer (e.g., Unger 1867, Bůžek et al. 1976). But the latter name is not suitable being based primarily on the leaf fossils from Häring, Austria (Santalum salicinum Ettingshausen 1853). Saporta (1889) recognized such a seed type as belonging to the Cedrelospermum group Aneuroptera, e.g. C. tenerum Saporta, C. abietinum Saporta etc. (Saporta 1889, pl. 18, fig. 5) and stressed the difficulties in delimiting affinities of such fossil winged seeds in general.

In addition to Cedrela $\mathrm{P}$. Br., which is also known in the fossil state (e.g. Meyer \& Manchester 1987, Oligocene of the John Day Formation, Oregon), generally similar winged seeds without distinct veins in the wing (Cedrela-like sensu Manchester) are produced by plants of very varied affinities. According to Manchester (personal communication June 2004), such seeds are common in the Malvaceae (Reevesia, Pterospermum, etc. - Kvaček 2006), but also occur in the Celastraceae R. Br. (Kokoona Thw. etc.), Ericaceae Juss. (Craibiodendron W.W. Smith), Eucryphiaceae Endl. (Eucryphia Cav.), Flacourtiaceae DC. (Carrierea Franch.), Altingiaceae Lindl. (Liquidambar L.), Hippocrateaceae Juss. (Campylostemon Welw., etc.), Ixonanthaceae Klotzsch (Ixonanthes Jack), Lythraceae Jaume St-Hil. (Lagerstroemia L.), Meliaceae Juss. (Toona M. Roem., Swietenia Jacq., etc.), Oleaceae Hoffmgg. \& Link. (Schrebera Roxb.), Onagraceae Juss. (Eucharidium Fisch. \& Mey.), Proteaceae Juss. (Embothrium J.R. \& G. Forst.), Ptaeroxylaceae Sonder (Cedrelopsis Baill., etc.), Rosaceae Juss. (Kageneckia Ruiz \& Pav.), Rutaceae Juss. (Chloroxylon DC.), Sapindaceae (Diplokeleba N.E. Br.), Theaceae Mirb. (Gordonia Ellis), and Vochysiaceae A. St-Hil. (Vochysia Aubl.). A detailed comparative study is beyond the scope of the present paper and we are adding information on the seed fossils mainly for future consideration. From the preliminary survey of winged seeds in several genera of Malvaceae, such as Nesogordonia (Fig. 9L), Helmiopsis H. Perrier, Helmiopsiella Arènes, Eriolaena (Fig. 9J), and Reevesia (Fig. 9M), those of Pterospermum (Fig. 9I, K, L) best match our fossils. Particularly, we have observed similar variation of the seed shape in fully ripened seeds (rounded forms) and unripe or aborted seeds (awl-shaped base) in one, and the same fruit in Pterospermum. The flattened form of the seed and the wing of Saportaspermum kovacsiae suggests that it should adhere flat to a solid wall (?capsule valve), as in Pterospermum, rather than packed in a broader locule with irregularities in the form, as in Gordoniopsis Grote \& Dilcher (1992). Unfortunately, the corresponding fruit remains, capsules or capsule valves that would reveal further traits, such as attachment and orientation of the seeds have not been recovered so far from Messel or any other sites.

A very similar type of seed compression has been de-

Figure 8. Cuticular structures of various fossil and living Malvaceae. • A - Byttneriopsis daphnogenes (Ettingshausen) Kvaček \& Wilde, comb. nov., abaxial cuticle with dense glandular trichome bases, Messel, SM.B Me 1595/1. • B - Byttneriopsis daphnogenes (Ettingshausen) Kvaček \& Wilde, comb. nov., abaxial cuticle of specimen shown in Fig. 2E with granular striate surface, Messel, SM.B Me 1452/1. • C - Byttneriopsis steuerii (Engelhardt) Kvaček \& Wilde comb. nov., abaxial cuticle of specimen shown in Fig. 3A with single glandular trichome base, Messel, SM.B Me 1428/1. - D - Byttneriopsis steuerii (Engelhardt) Kvaček \& Wilde comb. nov., abaxial cuticle of the holotype shown in Fig. 4C, D, Messel, phase contrast light, MDAR Me 1637/1. - E - Byttneriopsis spiegelii (Engelhardt) Kvaček \& Wilde comb. nov., abaxial cuticle of the holotype shown in Fig. 6A, Messel, MDAR Me 3436/1. $\bullet \mathrm{F}$ - adaxial cuticle of the same specimen. $\bullet \mathrm{G}$ - Eriolaena wallichii DC., abaxial cuticle showing massive base of a stellate trichome and a complete glandular barrel-shaped trichome, India Orientalis, Hooker \& Thomson $1859(\mathrm{P})$. $・ \mathrm{H}-$ Burretiodendron brilletii Kostermans, abaxial cuticle with cyclocytic stomata and a glandular trichome base, Tonkin, Brillet $19(\mathrm{P})$. All figures $\times 600$. 

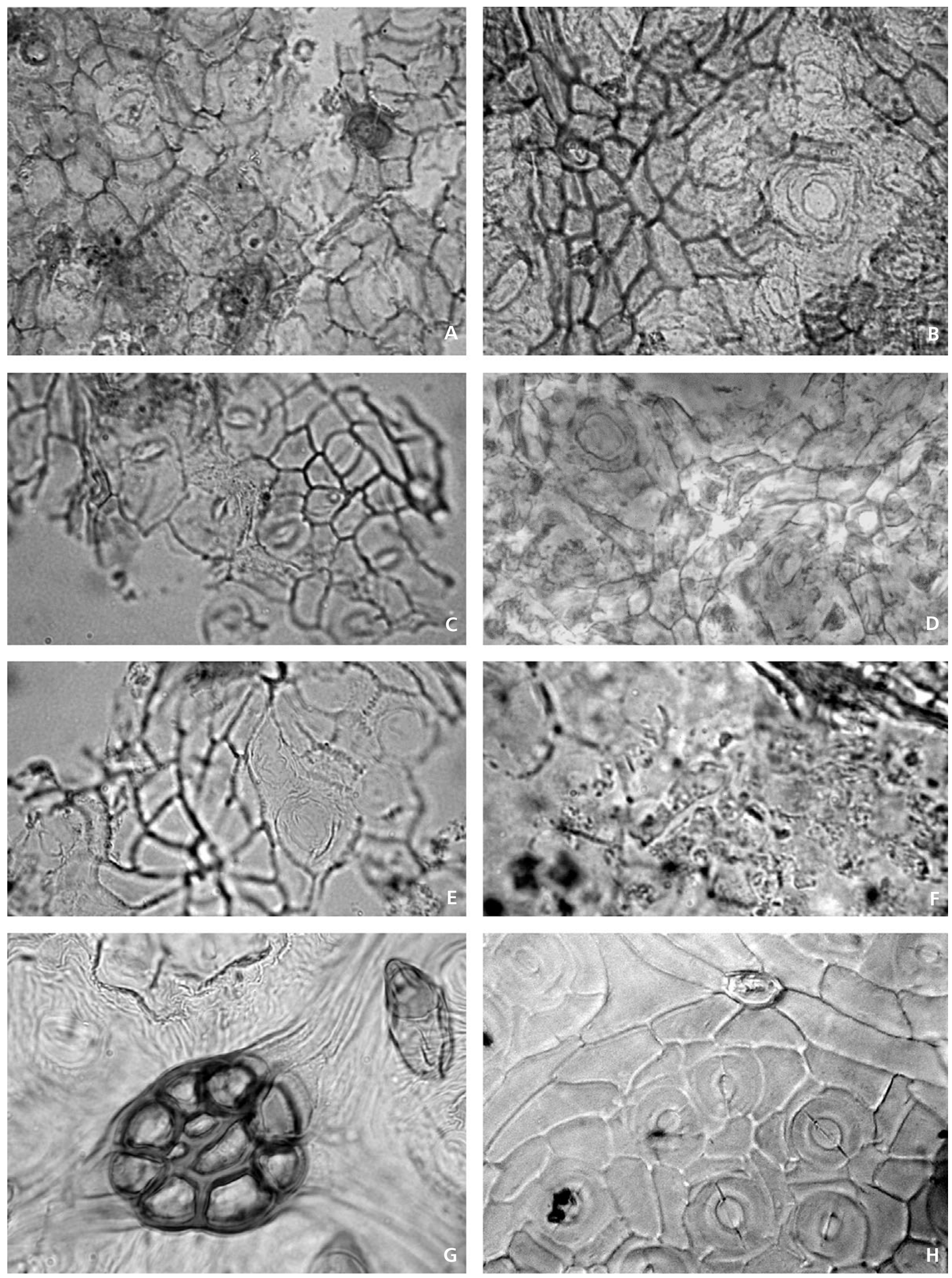
scribed from the Early Oligocene Seifhennersdorf site as Saportaspermum dieteri Walther \& Kvaček (2007). We hesitate to merge our material with this morphospecies on account of subtle differences in gross morphology (beak-like and strongly thickened seed bodies, and the only slightly bent form of the wing in our material) and very different associated foliage at the Eocene sites of Messel, Kučlín and Lábatlan versus that of the Oligocene flora of Seifhennersdorf.

\section{Comparison with the living Malvaceae s.I.}

Foliage forms similar to Byttneriopsis are produced by plants belonging to many diverse groups. The arguments why the studied foliage is in our opinion of malvalean affinity are mainly based on epidermal anatomy, although our search for the nearest living relatives of Byttneriopsis has relied in fact on composite characteristics of leaf architecture, epidermal anatomy and co-occurring winged seeds. The type of indumentum described above, namely the glandular trichomes and complex thickly cutinized trichome bases (Figs 6G, H, 7G), rules out many families with convergent leaf morphology, e.g. Matudaea Lundell (Hamamelidaceae), Sloanea L. (Elaeocarpaceae), Cinnamomum Schaefer and other lauroids and Ficus (Moraceae) with partly triveined leaves, when considering only groups occurring in the European Palaeogene.

Gross morphology of foliage offers hardly any differentiating characters to elucidate more precisely the generic affinities within the extant Malvaceae s.l. Similar entiremargined non-lobate leaf forms with symmetrical actinodromous venation occur generally in the Malvaceae s.l. We may list several genera, which contain species bearing foliage of similar forms. The venation may not be stable throughout a genus (e.g. Reevesia with both purely actinodromous and pinnate venation). We have excluded from our comparison representatives of mostly dentate foliage with chartaceous texture, such as Tilia L., Sparmannia L.f., Eriolaena and many others. Entire-margined leaf forms with firm texture similar to Byttneriopsis occur e.g. in the Byttnerioideae Burrett, Brownlowioideae Burret, Helicteroideae (Schott \& Endl.) Meisn. and Dombeyoideae Beilschm. But some of these are distinguished by asymmetrical or even subpeltate leaf bases.

The occurrence of glabrate leaves in the Malvaceae, as in
Byttneriopsis, is rare. Foliage of most members is pubescent with stellate trichomes to a varied degree of density and trichome types, at least on the undersurface of the leaf. Our limited collection of cuticular preparations does not contain samples, which would fully match the epidermal pattern of the above described morphospecies of Byttneriopsis. We have attempted to follow indications offered by co-occurrences of winged seeds obviously matching those of Pterospermum, Reevesia and others without success. Pterospermum, Eriolaena (Fig. 8G) and several other genera (Brownlowia Roxb., Schoutenia Korth., Hildegardia Schott \& Endl., Melhania Forsk.) are typical of massive, strongly cutinized, and sometimes elongate, trichome bases as in Byttneriopsis, which bear stellate trichomes often densely dispersed on the abaxial leaf side. Other genera have a varyingly dense indumentum of sessile stellate trichomes (Reevesia, Hainania Merr., Pentace Hassk., Colona Cav., Helicteres L.) or consisting of single, paired or rare fasciculate trichomes (Byttneria Loefl., Dombeya Cav., Craigia, partly Sterculia L.). We have found only a few cases of glabrate abaxial epidermis with cyclocytic stomata resembling our material, such as Burretiodendron Rehder Fig. 8H (B. esquirollii Rehder with peltate trichomes), Excentrodendron Chang \& Miau, Pterygota Schott \& Endl., and Scaphium Endl. Some species of Reevesia may resemble Byttneriopsis but differ in brachyparacytic stomata. Concluding this brief survey, we may state that Byttneropsis probably represents foliage of an extinct member of the Malvaceae s.l. sharing characters of several extant genera.

\section{Paleoecology of the studied Eocene Malvaceae}

According to the relatively thin cuticles of the material from Messel, the plants which produced Byttneriopsis foliage should have been deciduous. Deciduousness is not unusual even in warmer climates and may depend on the periodicity of precipitation (available humidity) during the year. However, thin cuticles with very similar patterns to Byttneriopsis are also produced by some evergreen Malvaceae, such as Burretiodendron and Excentrodendron. The possible analogues of these plants grow today under subtropical to paratropical conditions in East Asia and Central America (Reevesia, Pterospermum, Eriolaena). The fossil

Figure 9. Cedrelospermum kovaciae Kvaček \& Wilde sp. nov. (A-H) and seeds of living Malvaceae for comparison (I-M). • A - holotype, Messel, SM.B Me 5587. • B - anomalous seed with narrowed body, Messel, SM.B Me 4995. • C - refigured specimen of Cedrelospermum sp. 1 sensu Kovács (1959, fig. 7), Lábatlan, MAFI Bk 3460. • D - refigured specimen of Cedrelospermum sp. 2 sensu Kovács (1959, fig. 8), Lábatlan, MAFI Bk 3526. • E - poorly preserved seed, Lábatlan, MAFI Bk 3487. • F - enlarged seed part of Cedrelospermum sp. 1 sensu Kovács (1959, fig. 7), Lábatlan, MAFI Bk 3460. • G - seed impression, Mrtvý vrch at Kučlín, DB KsMr01. • H - counterimpression of carbonized seed, Messel, SM.B Me 8383b. - I - Pterospermum levinei Merr., Hainan, Fung 20331 (P). • J - Eriolaena candollii Wall., Thailand, van Beusecome \& Phengklai 2337 (P). - K - Pterospermum pierii Hance, two unequally sized seeds from the same capsule, Thailand, Pierre $3776(\mathrm{P})$. $・ \mathrm{~L}-$ Reevesia macrocarpa Li, Tonkin, Tsang $30473(\mathrm{P}) \cdot \bullet \mathrm{M}-$ Nesogordonia stylosa Perrier, Madagaskar, Capuron $247455 \mathrm{~F}(\mathrm{P})$. All figures $\times 3$ except F $\times 4.5$. 
Zlatko Kvaček \& Volker Wilde • Foliage and seeds of malvalean plants from the Eocene of Europe
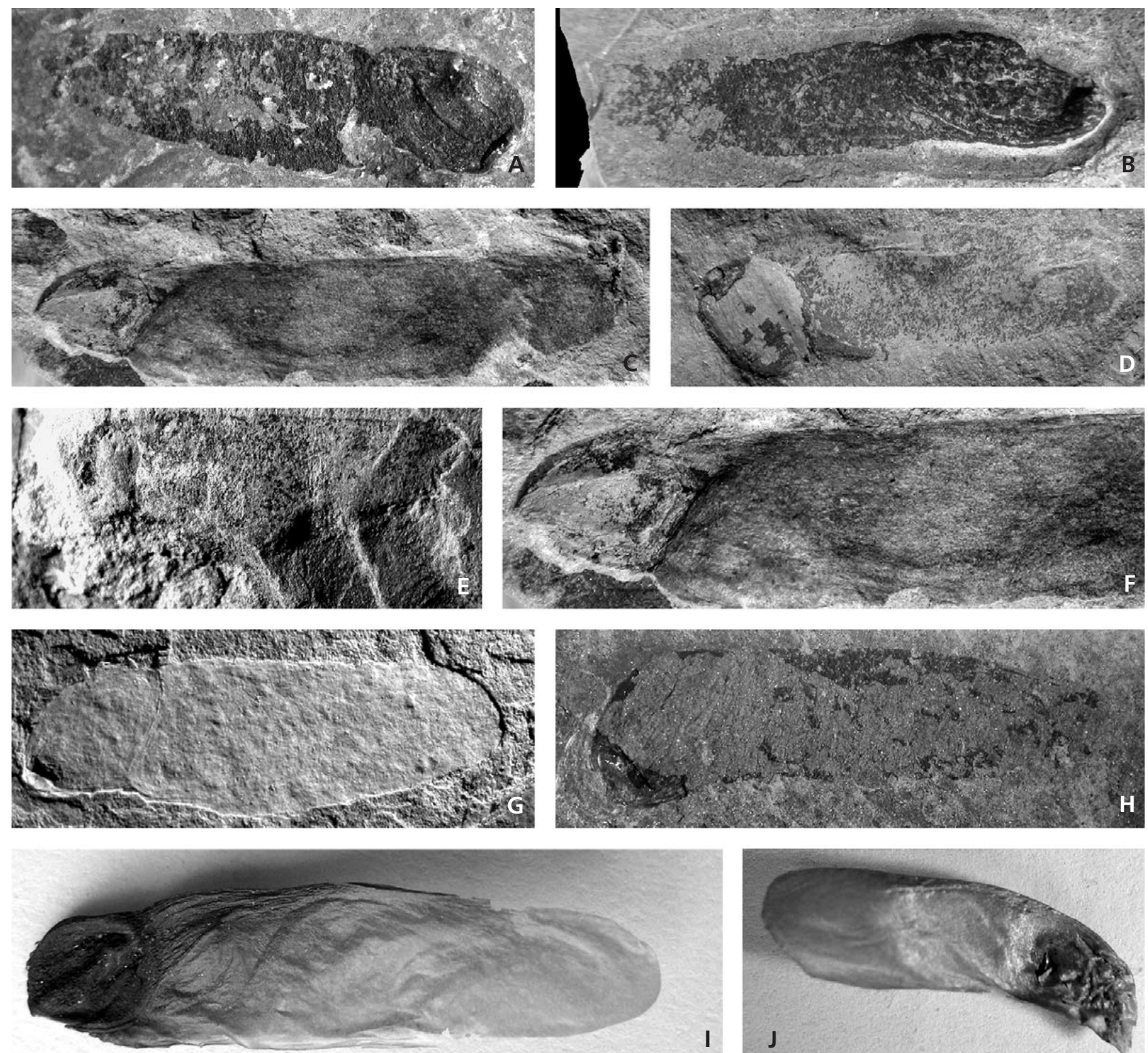

I
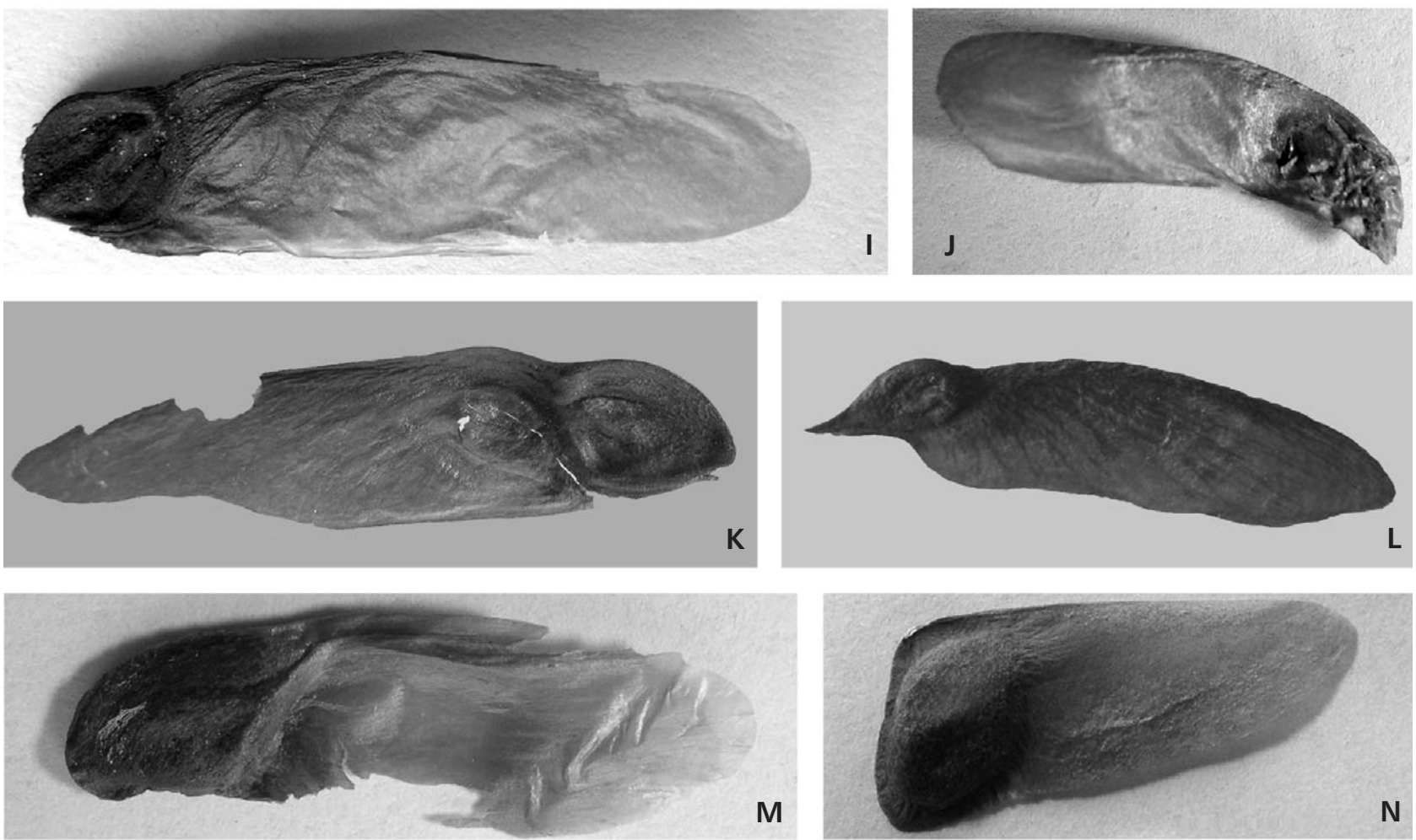
representatives were certainly zonal woody in view of the associated assemblages at Messel, Kučlín and Lábatlan. Leaf physiognomic climate proxies (CLAMP analyses) are not available for any of the three sites because of a largely unknown spectrum of leaf dicot morphotypes. The co-existence approach (Mosbrugger \& Utescher 1997), which is based on the autecology of comparable extant taxa, also fails in the case of such floras with extinct and also many unknown plants. The so far derived climatic conditions, based on general comparisons of the assemblages from Messel with living vegetation, led Wilde (2005) to suggest parallels with today's paratropical forests as defined by Wolfe (1979). However, the floras of Messel, Kučlín and Lábatlan differ in size categories of foliage, namely noto- to microphyllous, contrary to the paratropic forest vegetation with prevailing macrophyllous tress. Therefore, Kvaček (2010) proposed a new vegetation unit for such extinct European Palaeogene vegetation and called it "Mid-Latitude Broad-Leaved Notophyllous Evergreen Forest" characterized in general by dominating Lauraceae Juss., common and diversified Juglandaceae A. Rich. ex Kunth., Ulmaceae Mirb. (Cedrelospermum Saporta emend. Manchester), Leguminosae Juss., rare conifers (Tetraclinis Mast., partly azonal Doliostrobus Marion, Cephalotaxus Siebold \& Zucc.) and various accessory exotic and extinct elements. Representatives of true tropical families do not dominate and the diversity of the flora is moderate. Before revision of the floras is completed, it is difficult to suggest more precise palaeoclimatic proxy data. It is certain that the climate under which Byttneriopsis thrived was frostless, warm and humid, approximately similar to that of the monsoon areas of East Asia, namely today's south and southeast China, northern Vietnam and Laos.

\section{Acknowledgments}

This work was supported by the Grant Agency of the Czech Republic (GAČR), project No. 205/08/0643 and the research scheme No MSM 002162085, Czech Republic to the first author. Thanks are due to the curators of the Paris Herbarium $(\mathrm{P})$ who made the extant material of the Malvaceae accessible for study, and to Lilla Hably, Budapest, who organized the visit of the first author to Budapest. Jiř́ Kvaček, Prague, Zdeněk Dvořák, Bílina, and Barbara Meller, Vienna, all facilitated our study and the documentation of the plant fossils in the respective collections and are also acknowledged; Gabriele Gruber organized a short-term loan of type material from the Hessisches Landesmuseum Darmstadt. Co-operation with Grzegorz Worobiec, Kraków, in studying the leaf epidermal characters of the Malvaceae is much appreciated, as is technical and background support by Karin Schmidt and Martin Müller, Frankfurt am Main. Steven R. Manchester and Jakub Sakala provided helpful comments on the first version of the manuscript, and kindly reviewed and suggested improvements for the final form of our paper.

\section{References}

Alverson, W.S., Karol, K.G., Baum, D.A., Chase, M.W., Swensen, S.M., MCCOURT, R. \& SySTMA, K.J. 1998. Circumscription of the Malvales and relationships to other Rosidae: Evidence from $r b c L$ sequence data. American Journal of Botany 85, 876-887. DOI 10.2307/2446423

Alverson, W.S., Whitlock, B.A., NYFFELER, R., BAYER, C. \& BAUM, D.A. 1999. Phylogeny of core Malvales: evidence from $n d h F$ sequence data. American Journal of Botany 86, 1474-1486. DOI 10.2307/2656928

ANDREWS, H.N. 1970. Index of generic names of fossil plants 1820-1965. Geological Survey Bulletin 1300, 1-353.

VON BALTHAZAR, M., SCHÖNENBERGER, J., ALVERSON, W.S., JANKA, H., BAYER, C. \& BAUM, D.A. 2006. Structure and evolution of the androecium in the Malvatheca clade (Malvaceae s.1.) and implications for Malvaceae and Malvales. Plant Systematics and Evolution 260, 171-197.

BAyer, C., FAY, M.F., DE BRUIJn, A.Y., SAVOlainen, V., Morton, C.M., KubitzKi, K. \& ChASE, M.W. 1999. Support for an expanded family concept of Malvaceae within a recircumscribed order Malvales: A combined analysis of plastid $a t p B$ and $r b c L$ DNA sequences. Botanical Journal of the Linnean Society 129, 267-303.

BAYER, C. \& KUBITZKI, K. 2003. Malvaceae, 225-311. In KUBITZKI, K. \& BAYER, C. (eds) The families and genera of vascular plants V. Flowering plants - Dicotyledons, Malvales, Capparales and Non-betalain Caryophyllales. Springer, Berlin.

BÜŽEK, Č. 1971. Tertiary flora from the northern part of the Pětipsy area (North-Bohemian basin). Rozpravy Ústředního ústavu geologického 36, 1-118.

BÜŽEK, Č. \& KVAČEK, Z. 1994. An Early Miocene Linden (Tilia) from North Bohemia and its possible relationship. Acta Universitatis Carolinae, Geologica 1992(1-2), 97-102.

BƯŽEK, Č., HOLÝ, F. \& KVAČEK, Z. 1976. Tertiary flora from the Volcanogenic Series at Markvartice and Veselíčko near Česká Kamenice (České Středohoří Mts.). Sborník geologických věd, Paleontologie P.18, 69-132.

CHEEK, M. 2006. The validation of two new family names in Malvales: Durionaceae and Brownlowiaceae. Kew Bulletin $61,443$.

CHELIUS, C. 1886. Blatt Messel. 67 pp. Erlanger Geologische Karte Grossherzogthums Hesse $1: 25000$, first edition, Darmstadt.

COLLINSON, M.E. 1988. The special significance of the middle Eocene fruit and seed flora from Messel, West Germany. Courier Forschungsinstitut Senckenberg 107, 187-197.

Collinson, M.E., MANCHESTER, S.R., Wilde, V. \& HAYES, P. 2010. Fruit and seed floras from exceptionally preserved biotas in the European Paleogene. Bulletin of Geosciences 85(1), 95-102. DOI 10.3140/bull.geosci.1155

CRONQUIST, A. 1988. The evolution and classification of flowering plants. Second edition. 555 pp. New York Botanical Garden, Bronx, New York.

ENGELHARDT, H. 1922. Die alttertiäre Flora von Messel bei Darmstadt. Abhandlungen der Hessischen Geologischen Landesamt Darmstadt 7, 17-128.

ERDEI, B. \& RÁKOSI, L. 2009. The Middle Eocene flora of Csordakút (N Hungary). Geologica Carpathica 60(1), 43-57. DOI 10.2478/v10096-009-0005-4 
EtTingShausen, C. 1853. Die Tertiaerfloren der Oesterreichischen Monarchie. 2. Tertiäre Flora von Häring in Tirol. $A b$ handlungen der Kaiserlich-königlichen Geologischen Reichsanstalt, Serie II, Abteilung 3(2), 1-118.

ETtingshausen, C. 1866. Die fossile Flora des Tertiärbeckens von Bilin I. Denkschriften der Kaiserlichen Akademie der Wissenschaften, mathematisch-naturwissenschaftliche Klasse 28, 1-98.

ETtingshausen, C. 1868. Die fossile Flora des Tertiärbeckens von Bilin II. Denkschriften der Kaiserlichen Akademie der Wissenschaften, mathematisch-naturwissenschaftliche Klasse 28, 191-242.

EtTingshausen, C. 1869. Die fossile Flora des Tertiärbeckens von Bilin III. Denkschriften der Kaiserlichen Akademie der Wissenschaften, mathematisch-naturwissenschaftliche Klasse 29, 1-110.

GoTH, K. 1990. Der Messeler Ölschiefer, ein Algenlaminit. Courier Forschungsinstitut Senckenberg 131, 1-141.

GROTE, P.J. \& DilChER, D.L. 1992. Fruits and seeds of tribe Gordonieae (Theaceae) from the Eocene of North America. American Journal of Botany 79, 744-753. DOI 10.2307/2444939

HABLY, L. 1985. New data in the Eocene flora of Hungary. Annales Historico-Naturales Musei Nationalis Hungarici 77, $25-33$.

HABLY, L., ERDEI, B. \& KVAČEK, Z. 2001. $19^{\text {th }}$ century's palaeobotanical types and originals of the Hungarian Natural History Museum. 235 pp. Hungarian Natural History Museum, Budapest.

HABLY, L., KVAČEK, Z. \& MANCHESTER, S.R. 2000. Shared taxa of land plants in the Oligocene of Europe and North America in context of Holarctic phytogeography. Acta Universitatis Carolinae, Geologica 44(1), 48-71.

HEER, O. 1856. Flora Tertiaria Helvetiae, II. 110 pp. J. Wurster et comp., Winterthur.

HEER, O. 1859. Flora Tertiaria Helvetiae, III. 378 pp. J. Wurster et comp., Winterthur.

Heywood, V.H., Brummitt, R.K., Culham, A. \& SeberG, O. 2007. Flowering plant families of the world. 424 pp. Royal Botanic Gardens, Kew.

JUDD, W.S. \& MANCHESTER, S.R. 1997. Circumscription of Malvaceae (Malvales) as determined by a preliminary cladistic analysis of morphological, anatomical, palynological, and chemical characters. Brittonia 49, 384-405. DOI $10.2307 / 2807839$

KNOBLOCH, E. \& KVAČEK, Z. 1965. Byttneriophyllum tiliaefolium (Al. Braun) Knobloch et Kvaček in den tertiären Floren der Nordhalbkugel. Sborník geologických věd, Paleontologie P.5, 123-166.

KNOBLOCH, E. \& KVAČEK, Z. 1976. Miozäne Blätterfloren vom Westrand der Böhmischen Masse. Rozpravy Ústředního ústavu geologického 42, 1-131.

KnOBloch, E., KonZalovÁ, M. \& KVAČEK, Z. 1996. Die obereozäne Flora der Staré Sedlo-Schichtenfolge in Böhmen (Mitteleuropa). Rozpravy Ústředního ústavu geologického 49, 1-260.

KovÁCS, É. 1959. Note sur la flore Éocène de Lábatlan (Transdanubie du Nord). Annales Universitatis Scientiarum Budapestinensis de Rolando Eötvös Nominatae, Sectio Biologica 2, 135-140.
KovÁCS, É. 1961. Középsö-Eocén flóra Lábatlanrôl [Mitteleozäne Flora aus der Umgebung von Lábatlan]. Magyar Állami Földtani Intézet Évi Jelentése az 1957-8, 473-495. [in Hungarian]

Kovar-Eder, J., KvačeK, Z. \& Ströbitzer-Hermann, M. 2004. The Miocene Flora of Parschlug (Styria, Austria) - revision and synthesis. Annalen des Naturhistorischen Museums Wien, 105 A, 45-159.

KRASSILOV, V.A. 1979. Melovaya flora Skhalina [Cretaceous flora of the Skhalin Island]. Nauka, Moscow. [in Russian]

KRUTZSCH, W. 2004. Neue Untersuchungen über präquartären Malvaceen-Pollen aus den Unterfamilien der Tilioideae, Helicteroideae und Bombacoideae. Palaeontographica Abteilung B 267, 67-160.

KRYSHTOFOVICH, A.N. \& BORSUK, M. 1939. Contribution to the Miocene flora from western Siberia. Problems of Palaeontology 6, 375-394.

KVAČEK, Z. 2002. Late Eocene landscape, ecosystems and climate in northern Bohemia with particular reference to the locality Kučlín near Bílina. Bulletin of the Czech Geological Survey 77, 217-236.

KVAČEK, Z. 2004. Early Miocene records of Craigia (Malvaceae s.1.) in the Most Basin, North Bohemia - whole plant approach. Journal of the Czech Geological Society 49, 161-171.

KVAČEK, Z. 2006. Fossil fruits of Reevesia (Malvaceae, subfam. Helicteroideae) and associated plant organs (seeds, foliage) from the Lower Miocene of North Bohemia (Czech Republic). Neues Jahrbuch für Geologie und Paläontologie Monatshefte 2006, 431-448.

KVAČEK, Z. 2008. The role of types in palaeobotanical nomenclature. Acta Musei Nationalis Pragae, Series B - historia naturalis 64, 89-96.

KVAČEK, Z. 2010. Forest flora and vegetation of the European early Palaeogene - a review. Bulletin of Geosciences 85(1), $3-16$.

KVAČEK, Z. \& WALTHER, H. 2004. Oligocene flora of Bechlejovice at Děčín from the neovolcanic area of the České Středohoři Mountains, Czech Republic. Acta Musei Nationalis Pragae, Series B - historia naturalis 60, 9-60.

KVAČEK, Z., MANCHESTER, S.R. \& AKHMETIEV, M.A. 2005. Review of the fossil history of Craigia (Malvaceae s.l.) in the Northern Hemisphere based on fruits and co-occurring foliage, 114-140. In AKHMETIEV, M.A. \& HERMAN, A.B. (eds) Transaction of the international palaeobotanical conference, Moscow, May 17-18, 2005. Modern problems of palaeofloristics, palaeophytogeography and phytostratigraphy. GEOS, Moscow.

KVAČEK, Z., TEOdORIDIS, V. \& GREGOR, H.-J. 2008. The Pliocene leaf flora of Auenheim, Northern Alsace (France). Documenta Naturae 155(10), 1-108.

LAURENT, L. 1904-1905. Flore Pliocène des cinérites du Pasde-la-Mougudo et de Saint-Vincent-La Sabie (Cantal). Annales du Muséum d'Histoire Naturelle de Marseille, Geologie 9, 1-313.

LENZ, O.K., WILDE, V. \& RIEGEL, W. 2007. Recolonization of a Middle Eocene volcanic site: quantitative palynology of the initial phase of the maar lake of Messel (Germany). Review of Palaeobotany and Palynology 145, 217-242.

DOI 10.1016/j.revpalbo.2006.11.001 
MAI, D.H. \& WALTHER, H. 1991. Die oberoligozänen und miozänen Floren NW-Sachsens und des Bitterfelder Raumes. $A b$ handlungen des Staatlichen Museums für Mineralogie und Geologie zu Dresden 38, 1-230.

MANCHESTER, S.R. 1987. The fossil history of the Juglandaceae. Monographs in systematic botany from the Missouri Botanical Garden 21, 1-137.

MANCHESTER, S.R. 1989. Systematics and fossil history of the Ulmaceae. Systematic Association Special Volume 40B, 221-251.

MANCHESTER, S.R. 1994. Inflorescence bracts of fossil and extant Tilia in North America, Europe and Asia: patterns of morphologic divergence and biographic history. American Journal of Botany 81, 1176-1185. DOI 10.2307/2445480

MANCHESTER, S.R., COllinson, M.E. \& GoTH, K. 1994. Fruits of the Juglandaceae from the Eocene of Messel, Germany, and implications for Early Tertiary phytogeographic exchange between Europe and western North America. International Journal of Plant Sciences 155, 388-394. DOI 10.1086/297176

MANCHESTER, S.R., CHEN ZHIDUAN \& ZHOU ZHEKUN 2006. Wood anatomy of Craigia (Malvales) from southeastern Yunnan, China. IAWA Journal 27(2), 129-136.

MANCHESTER, S.R., WiLDE, V. \& COLLINSON, M.E. 2007. Fossil cashew nuts from the Eocene of Europe: biogeographic links between Africa and South America. International Journal of Plant Sciences 168(8), 1199-1206. DOI $10.1086 / 520728$

MASSALONGO, A. 1854. Monografia delle Dombeyacee fossili. $25 \mathrm{pp}$. Verona.

MeYER, W. \& MANCHESTER, S.R. 1997. The Oligocene Bridge Creek flora of the John Day Formation, Oregon. University of California Publications in Geological Sciences 141, 1-195.

MosbrugGer, V. \& UTESCHER, T. 1997. The coexistence approach - a method for quantitative reconstructions of Tertiary terrestrial palaeoclimate data using plant fossils. Palaeogeography, Palaeoclimatology, Palaeoecology 134, 61-86. DOI 10.1016/S0031-0182(96)00154-X

SAPORTA, G. 1889. Dernières adjunctions à la flore fossile d'Aix-en-Provence. Annales des Sciences Naturelles, Botanique, Série 7, 7, 1-104.

SCHAARSCHMIDT, F. 1982. Präparation und Untersuchung der eozänen Pflanzenfossilien von Messel bei Darmstadt. Courier Forschungsinstitut Senckenberg 56, 59-77.

SCHAARSCHMIDT, F. \& WILDE, V. 1986. Palmenblüte und -blätter aus dem Eozän con Messel. Courier Forschungsinstitut Senckenberg 86, 177-202.

SCHIMPER, W.P. 1874. Traité de Paléontologie Végétale. 3.896 pp. J.B. Baillière et fils, Paris.

STURM, M. 1971. Die eozäne Flora von Messel bei Darmstadt. I. Lauraceae. Palaeontographica, Abteilung B 134, 1-60.

SMith, S.Y., Collinson, M.E. \& Rudall, P.J. 2008. Fossil Cyclanthus (Cyclanthaceae, Pandanales) from the Eocene of Germany. American Journal of Botany 95, 688-699. DOI 10.3732/ajb.2007390

SMiTH, S.Y., COLLINSON, M.E., Simpson, D.A., RudAll, P.J., MARONE, F. \& STAMPANONI, M. In press. Elucidating the affinities and habitat of ancient, widespread Cyperaceae: Volkeria messelensis gen. et sp. nov., a fossil mapanioid sedge from the Eocene of Europe. American Journal of Botany.
Soltis, D.E., Soltis, P.S., Endress, P.K. \& Chase, M.W. 2005. Phylogeny and evolution of angiosperms. $370 \mathrm{pp}$. Smithsonian books, Washington.

TAKHTAJAN, A. 1980. Outline of the classification of flowering plants (Magnoliophyta). Botanical Review 46, 225-359. DOI $10.1007 / \mathrm{BF} 02861558$

TAKHTAJAN, A. 1997. Diversity and classification of flowering plants. 643 pp. Columbia University Press, New York.

TANAI, T. 1989. The revision of the so-called "Alangium" leaves from the Paleogene of Hokkaido, Japan. Bulletin of the National Science Museum, Series C (Geology \& Palaeontology) 15(4), 121-149.

THORNE, R.F. 1992. An updated phylogenetic classification of the flowering plants. Aliso 13, 365-389.

UNGER, F. 1850a. Genera et species plantarum fossilium. XL and 627 pp. W. Braunmüller, Vindobonae.

UNGER, F. 1850b. Die fossile Flora von Sotzka. Separatum. Denkschriften der kaiserlichen Akademie der Wissenschaften, mathematisch-naturwissenschaftliche Klasse 2, 127-197.

UNGER, F. 1867. Die fossile Flora von Kumi auf der Insel Euboea. Denkschriften der kaiserlichen Akademie der Wissenschaften, mathematisch-naturwissenschaftliche Klasse 27, $1-66$.

WALTHER, H. \& KVAČEK, Z. 2007. Early Oligocene Flora of Seifhennersdorf (Saxony). Acta Musei Nationalis Pragae, Series $B$ - historia naturalis $63,85-174$.

WILDE, V. 1989. Untersuchungen zur Systematik der Blattreste aus dem Mitteleozän der Grube Messel bei Darmstadt (Hessen, Bundesrepublik Deutschland). Courier Forschungsinstitut Senckenberg 115, 1-215.

WILDE, V. 2004. Aktuelle Übersicht zur Flora aus dem mitteleozänen "Ölschiefer" der Grube Messel bei Darmstadt (Hessen, Deutschland). Courier Forschungsinstitut Senckenberg $252,109-114$.

WILDE, V. 2005. The Green Eocene. The diverse flora of a paratropical climate. Vernissage UNESCO World Heritage Series 21(151), 14-19.

WILDE, V. \& FRANKENHÄUSER, H. 1999. Comptonia like leaves from the German Middle Eocene. Acta Palaeobotanica Supplementum 2, 447-463.

WILDE, V., KVAČEK, Z. \& Bogner, J. 2005. Fossil leaves of the Araceae from the Eocene of Europe. International Journal of Plant Sciences 166, 157-183. DO] 10.1086/425673

WILDE, V. \& MANCHESTER, S.R. 2003. Cedrelospermum-fruits (Ulmaceae) and related leaves from the Middle Eocene of Messel (Hesse, Germany). Courier Forschungsinstitut Senckenberg 241, 147-153.

WILDE, V. \& SCHAARSCHMIDT, F. 1993. High resolution CLSM-studies of in-situ preserved pollen from the Messel oil shale. Scientific and Technical Information 10(6), 209-214.

WOLFE, J. 1977. Paleogene floras from the Gulf of Alaska region. US Geological Survey Professional Papers 997, 1-108.

Worberg, A., Alford, M.H., QuANDT, D. \& Borsch, T. 2009. Huerteales sister to Brassicales plus Malvales, and newly circumscribed to include Dipentodon, Gerrardina, Huertea, Perrottetia, and Tapiscia. Taxon 58, 468-478.

WOROBIEC, G. 2003. New fossil flora from the Neogene deposits in the Bełchatów lignite mine. Acta Palaeobotanica Supplement 3, 3-133. 